\title{
Kontexty minoritnej kultúry
}

\author{
Jaroslav Čukan - Linda Čukanová - Boris Michalík - Marian Žabenský \\ Filozofická fakulta UKF v Nitre, Štefánikova 67, Nitra, Slovenská republika
}

Do redakce doručeno 28. července 2017; k publikaci přijato 2. listopadu 2017

\section{CONTEXTS OF MINORITY CULTURE}

ABSTRACT The aim of present study is to introduce and interpret specific and generally little-known living and culture of Bedouins as a cultural and language minority in difficult processes of cultural transitions from 1970's by the year 2010. We are considering ecological, social, confesional, economical and political contexts of Bedouins identity. We are comparing Bedouins living and culture with majority environment. Present issue meets sociocultural anthropology (ethnology, cultural ecology) and cultural geography. Repeated short term field research in Syrian desert were realized by ethnologist J. Čukan (Slovak) who is also an author of photos and his former colleague - historian and journalist Al-Absi (Arab from Syria) in period 2006-2010.

KEY WORDS cultural minority; Bedouin culture; identity factors; economical activities; intergenerational and interpersonal family relations; tradition and cutlural transition; influence of globalization; armed conflicts

ABSTRAKT Cielom našej štúdie je predstavit a interpretovat’ jedinečný, no vo všeobecnosti málo známy spôsob života beduínov ako kultúrnej a jazykovej minority v zložitých procesoch kultúrnych zmien od 70. rokov 20. storočia do roku 2010. Naznačujeme ekologické, sociálne, konfesionálne, ekonomické aj politické kontexty beduínskej identity. Spôsob života a kultúru beduínov porovnávame s majoritným prostredím. Problematika zasahuje do sociokultúrnej antropológie (etnológia, kultúrna ekológia) a kultúrnej geografie. Opakované krátkodobé terénne výskumy beduínskej kultúry v priestore Sýrskej púšte vykonal etnológ J. Čukan (Slovák), ktorý je aj autorom fotografí́, s kolegom - historikom a žurnalistom Al-Absim (Arab zo Sýrie) v rokoch 2006-2010.

KL'ÚČOVÉ SLOVÁ kultúrna minorita; beduínska kultúra; faktory identity; ekonomické aktivity; medzigeneračné a interpersonálne vztahy $\mathrm{v}$ rodine; tradícia a kultúrna zmena; vplyv globalizácie; vojnové konflikty

\section{KONTEXTY PRIESTORU, ČASU A KULTÚRY}

Človek a kultúra sa vždy formujú a pôsobia v určitom priestore a čase. Vytvárajú tak vztahový kruh človek - kultúra priestor - čas ${ }^{1}$. V rámci adaptácie človeka na prírodné prostredie dochádza medzi kultúrou a krajinou k vzájomnému ovplyvňovaniu. Treba však prihliadat' aj na politickú situáciu, ekonomické aspekty a d’alšie vonkajšie vplyvy, ktoré sú v niektorých obdobiach relevantné.

Beduínske kmene v priestore Sýrskej púšte formovali a inovovali svoju kultúru podla možností, ktoré im poskytovalo prírodné prostredie. Vznikla kultúrna krajina, pozostávajúca

1 Heřmanová - Chromý a kol. $(2009,16)$ hovoria o vztahovom trojuholníku kultúra - priestor - čas. prevažne $\mathrm{z}$ roztratených príležitostných sídel nomádov, pasienkov a zdrojov vody. V súčasnosti je sotva možné hovorit’ o prírodnej krajine, pretože človek tu naštartoval zmeny, ktoré modifikovali jej podstatu (Havrlant - Buzek 1985, 23). Príkladom je štúdia zameraná na vplyv pasenia oviec na druhovú pestrost' rastlín v krajinných depresiách Sýrie. Louhaichi a kol. poukázali na skutočnost', že druhová rozmanitost a štruktúra flóry je v spásaných územiach nižšia. Je všeobecne známe, že vypásaním sa zabraňuje aj obnove lesných porastov. (Príkladom môže byt pôvodne zalesnená Stara planina v Bulharsku.) Pôvodné sýrske lesy boli vyrubované v súvislosti s intenzívnou aktivitou rôznych kultúr hlavne v dobe bronzovej, železnej a grécko-rímskej. Dochádzalo aj k masívnemu rozvoju polnohospodárstva (Philip a kol. 2007, 233-242; Philip a kol. 2008, 21-42). Tieto faktory spôsobili postupnú preme- 


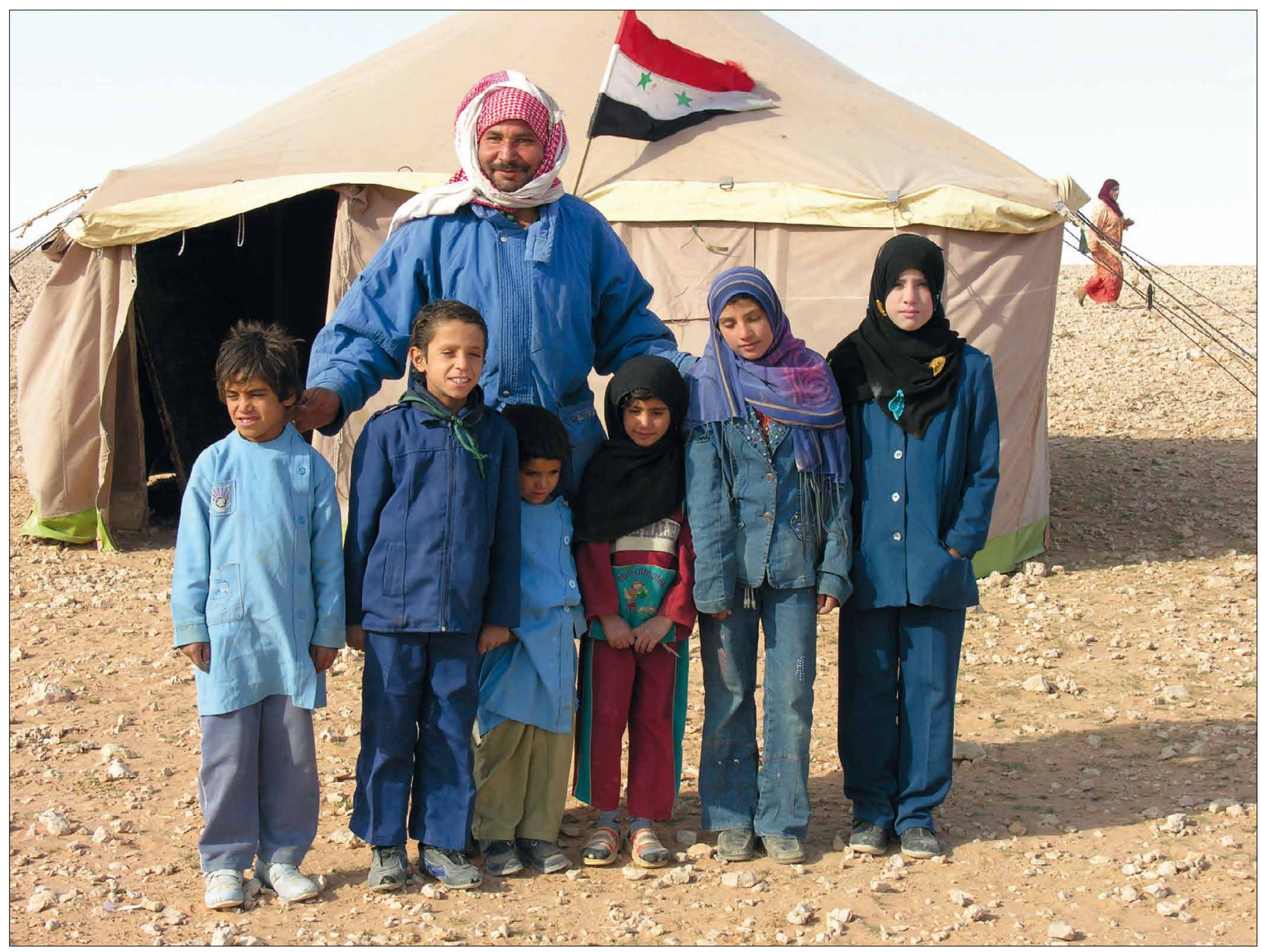

Obr. 1. Žiaci s učitelom pred školou v púšti, 2006.

nu vnútrozemia Sýrie na púšt'. Polopúštne a púštne oblasti vyhovovali kočovnému spôsobu života a rozvoju beduínskej subkultúry. Vyvíjala sa izolovane a konzervovala staršie vrstvy arabskej kultúry. Vplyv na vývoj kultúrnej krajiny malo aj budovanie železníc. Prvé trate Damask - Bejrút (Libanon) a Damask - Medina (Saudská Arábia) boli sprevádzkované v rokoch 1895 a 1908 (Hughes 1981, 17). Na pohon parnej železnice boli potrebné zásoby vody a dreva. Začiatkom 20. storočia preto dochádza k zintenzívneniu výrubu zvyškov lesných porastov aj vo vzdialenejších oblastiach od železničnej trate, čo urýchlilo dezertifikáciu celej krajiny. Ako uvádza Frantzman a Kark $(2011,6)$ v tomto období dochádza k snahe Osmanskej ríše o zastavenie, prípadne spomalenie procesu šírenia púští. Prioritou bolo polnohospodárstvo. Dochádza $\mathrm{k}$ rozvoju pestovania kukurice. Beduíni ako nomádni pastieri sa polnohospodárskym činnostiam vyhýbali, svojou dlhodobou pastierskou aktivitou $\mathrm{v}$ dnešných púštnych a polopúštnych oblastiach výrazne ovplyvnili schopnost' regenerácie pôvodných porastov (Louhaichi a kol. 2012, 101-106) a kultúrne sa tak vzdalovali od usadlej arabskej majority s odlišnou stratégiou spôsobu života.
V poslednej tretine 20. storočia nastáva zmena spôsobu života beduínov $\mathrm{z}$ nomádskeho na polonomádsky až usadlý. V polopúštnej a púštnej krajine vzniká vel'ký počet beduínskych dedín a pôvodné rolnícke sú dosídlované. Shmueli (1980, 253-254) v štúdii zameranej na beduínov v Izraeli s akcentom na zmeny sídelných štruktúr (závery možno aplikovat aj na územie dnešnej Sýrie) uvádza, že k týmto skutočnostiam došlo na základe viacerých faktorov. Prvým je prítomnost' silnej vlády schopnej udržat' bezpečnost', čím sa zredukovali príjmy z lúpeží a ochranných poplatkov za prechod kmeňovým územím. Významné bolo aj zavedenie motorových vozidiel, ktoré prakticky anulovali význam beduínskych obchodných karaván a umožnili dochádzat do zamestnania. Mladú generáciu ovplyvnil školský systém, ktorý ukázal nové možnosti uplatnenia. Pre beduínske vidiecke sídla bola spočiatku charakteristická chýbajúca infraštruktúra, značná rozptýlenost', absencia centra a služieb (Shmueli 1980, 254). V posledných desatročiach však dochádza $\mathrm{k}$ reorganizácii sídelných štruktúr.

V súčasnosti prírodné prostredie prestalo byt determinantom formovania kultúry hlavne v Európe a USA. Globalizácia spo- 


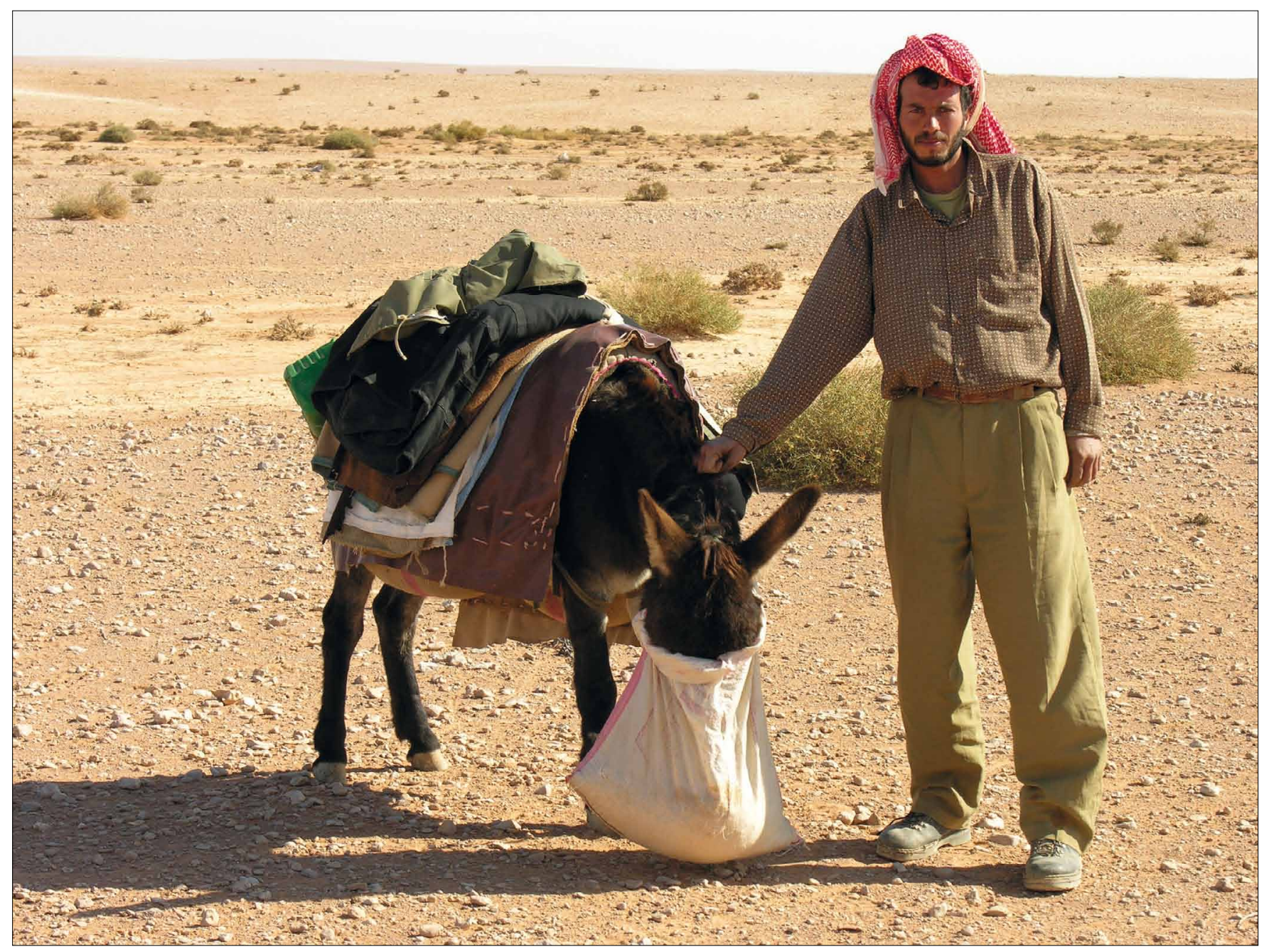

Obr. 2. Kočovný pastier, 2006.

jená s difúziou kultúrnych prvkov ovplyvňuje do určitej miery aj spoločenstvá beduínov. Stále sú však závislé aj od prírodného prostredia.

Zaujímavé kontexty ponúka vztah medzi klimatickými zmenami, modifikáciami ekonomického systému beduínov a ich identitou v pôvodnom prostredí púšte, na hranici kočovného a usadlého spôsobu života a v stálych sídlach. Príspevok tak dopÍňa a rozširuje doteraz prezentované výsledky výskumu a štúdia relatívne vzdialenej kultúry Blízkeho východu a moslimského sveta, objasňuje spätost' konfesionality a kultúry, respektíve upozorňuje na náboženský determinizmus, rieši otázky identity kultúrnej minority a jej koexistencie $\mathrm{s}$ majoritným prostredím a $\mathrm{v}$ neposlednom rade poskytuje konkrétne príklady z oblasti kultúrnej ekológie. Rozhodujúcimi faktormi formovania beduínskej subkultúry a vedomia jej skupinovej príslušnosti sú predovšetkým dva limity: prírodné prostredie a moslimské vierovyznanie, ktoré determinujú všetky oblasti spôsobu života a kategórie kultúrnych hodnôt vrátane psychickej, mentálnej a etnokultúrnej kompatibility $\mathrm{s}$ Európou v najširších súvislostiach. Úvodom treba pripomenút, že naše terénne výskumy boli definitívne prerušené vojnovými konfliktami v Sýrii aj v okolitých krajinách Blízkeho východu. Viaceré indície naznačujú, že vojna spôsobila koniec tradičných kočovníckych komunít $\mathrm{v}$ tomto geografickom a etnokultúrnom regióne, zánik stáročia formovaných kultúrnych postupov a v konečnom dôsledku aj kontinuitu ich výskumu a štúdia.

\section{IDENTITA BEDUÍNOV}

Základom akejkolvek kolektívnej identity je uvedomenie si inakosti vlastnej skupiny od iných, možnost'/dôvod rozlíšenia my - oni. Skrátka - keby neexistovali oni, nebolo by ani našej identity, nemali by sme sa s kým porovnávat' a od koho odlišovat. Ja sa identifikujem so skupinou, lebo som, alebo chcem byt' jej členom, na jej strane. Naša identita by neexistovala bez iných. Dôvodom polarizácie/diferenciácie môžu byt' mnohé spoločné, respektíve odlišné charakteristiky, napríklad rasová, etnická, konfesionálna, politická, jazyková, profesijná, sociálna, rezidenčná a vo všeobecnosti vlastnenie a praktizovanie najrôznejších kultúrnych vzorov. Všetci beduíni sú Arabi, 


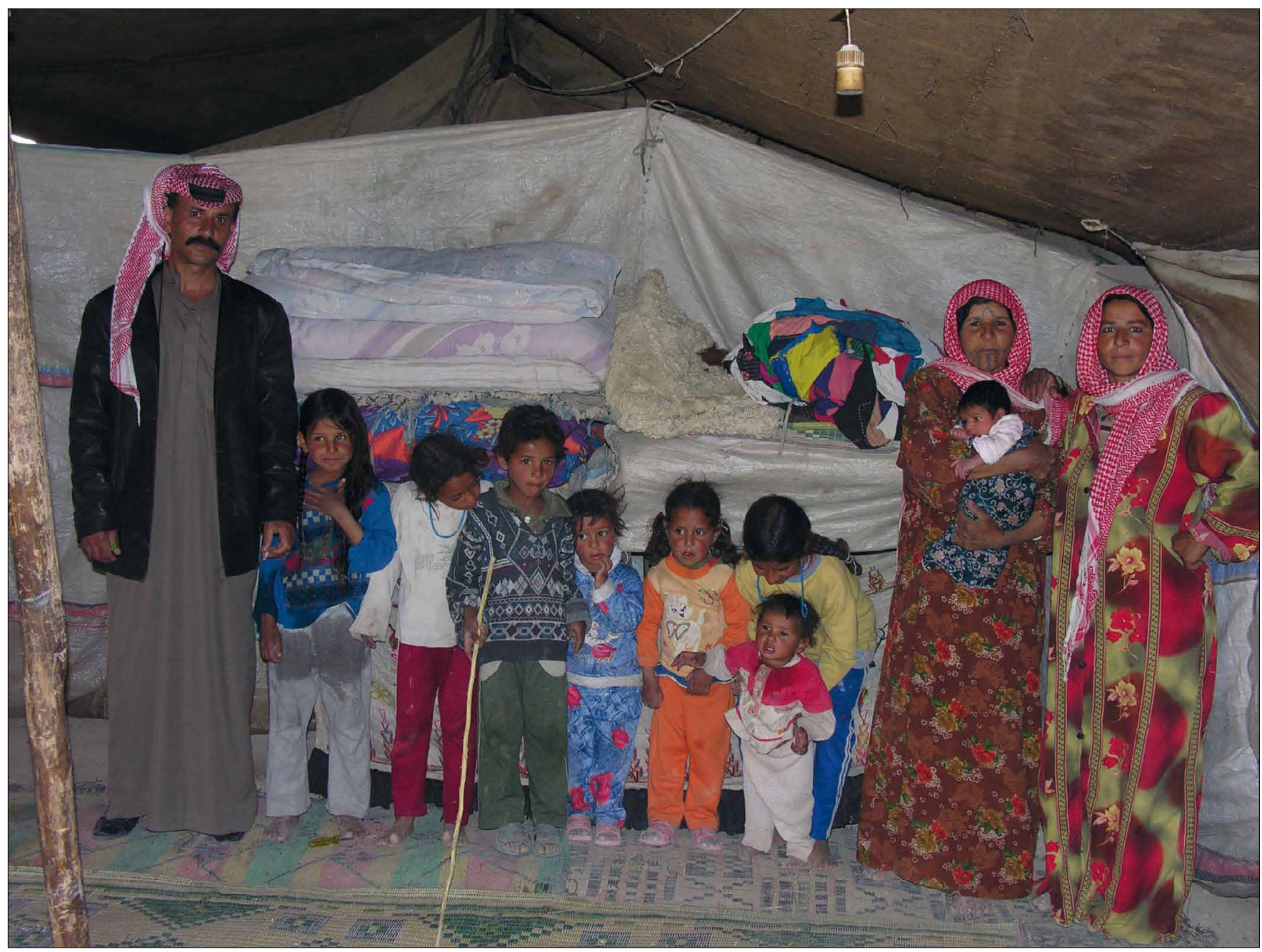

Obr. 3. Rodina, 2008.

preto v Sýrii, a ani v inom blízkovýchodnom (alebo severoafrickom) štáte $s$ absolútnou prevahou arabského obyvatel'stva nie sú diferenciačným činitelom a indikátorom skupinovej identity rasové parametre ${ }^{2}$ ani odlišnosti súvisiace $s$ fenoménom národ a štát.

$\mathrm{V}$ arabskom svete má moslimská viera rozhodujúce, no nie výhradné zastúpenie. Aj medzi beduínmi sa nájdu krestania, hoci v minimálnom počte. Vo všetkých arabských štátoch nie je situácia analogická. Na prvý pohlad by sa mohlo zdat, že vierovyznanie, respektíve náboženská príslušnost' nie je rozhodujúcim faktorom, ktorý ovplyvňuje identitu beduínov. Konfesionalita však často nadobúda aj politické kontexty. Aj obyvatel' „západného sveta“ eviduje polarizáciu moslimské-

2 Napriek takémuto konštatovaniu treba pripomenút konštatovanie informátorov - nie beduínov, že jedným z diferencujúcich príznakov medzi majoritným obyvatelstvom a beduínskou minoritou je tmavšia farba pleti beduínov. Môže byt' výsledkom biologickej adaptácie organizmu na nepretržité pôsobenie klimatických faktorov, na rozdiel od usadlého obyvatel'stva podstatne intenzívnejšie. ho sveta minimálne na sunnitský a šíitsky a v takomto rámci ju treba vnímat' aj u beduínov. Nemožno to však už povedat' o samotnej viere, o žití a prežívaní náboženstva. S určitostou je diferenciačným faktorom hĺbka, sila a pravost viery beduínov. Hospodárstvo a ich spôsob života závisia od prírody. Je jedno, či v Sýrskej púšti, alebo v skalnatých horách Jemenu, kde beduíni, známi ako „muži kvetov“, živia svoje rodiny ako pastieri kôz a rolníci na vysokohorských terasovitých políčkach. Beduín stále prosí Boha a stále Bohu d’akuje. Spolieha sa len na Boha. Odvoláva sa na neho v dobrom i zlom. Preto je jeho viera taká silná a možno ju považovat’ za základ jeho bytia, hlavný životný princíp, dôležitý faktor uvedomovania si svojej osobitosti a odlišnosti vo vzţahu k iným skupinám a vrstvám obyvatel'stva. Beduín je presvedčený, že vztah medzi ním a Bohom je užší ako medzi Bohom a iným moslimom. Obyvatelia dedín a miest pravidelne navštevujú mešitu, no nemôžu mat' k nemu tak blízko, nezávisia tak od neho. Beduín v púšti si nemôže dovolit' vo viere polavit'. Neverí formálne, ale hlboko, úprimne. Dôkazom jeho najhlbšej a najčistejšej viery a zároveň aj odmenou za vieru je, 


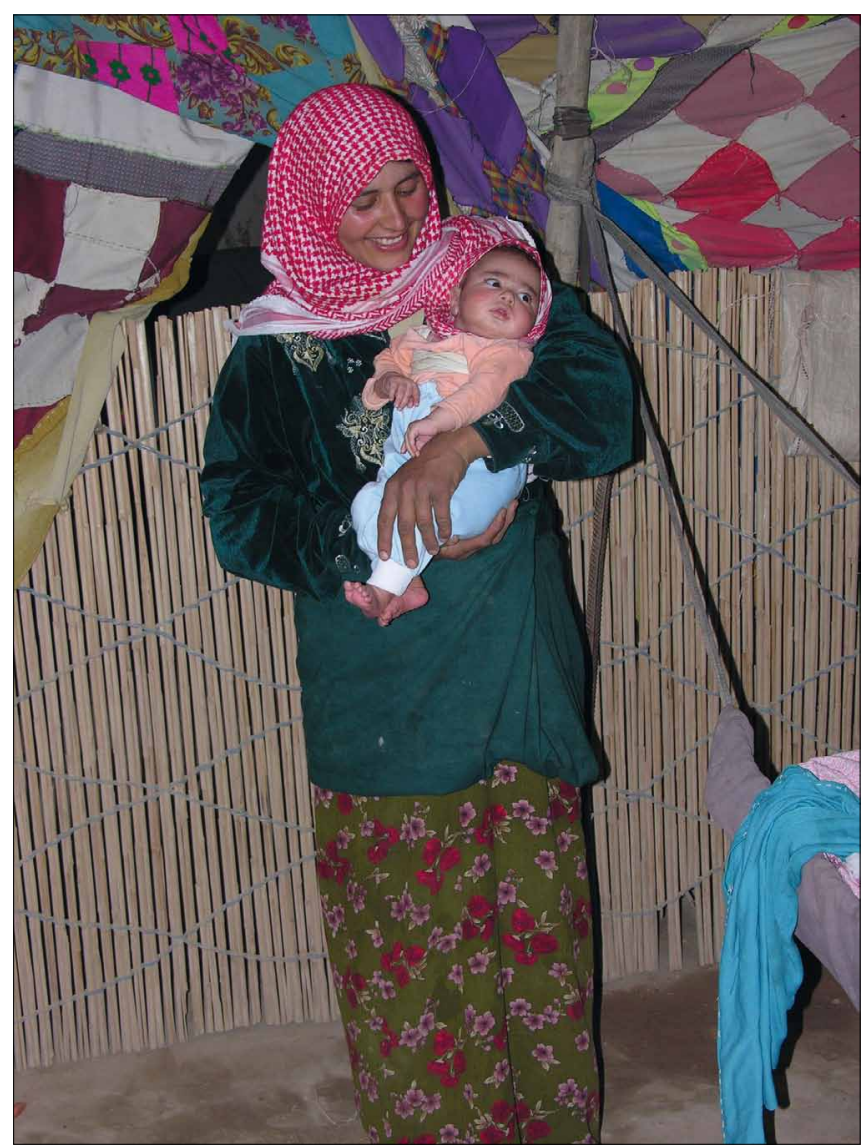

Obr. 4. Matka s dietatom, 2008.

že mu je dopriate každé ráno sa zobudit a vidiet svoje deti a živé stádo ${ }^{3}$. Nemôže to ovplyvnit svojim logickým a racionálnym myslením, lebo vždy sa stane to, čo chce Boh.

Podstatou identity beduínov je viacvrstvové presvedčenie o svojej výnimočnosti a skupinovej odlišnosti. Okrem najužšieho vztahu s Bohom je jedným z najvýznamnejších faktorov beduínskej identity a etnocentrizmu spôsob života odvodený od kočovného pastierstva v púšti. Ja som beduín. Pravý Arab. Mám stádo. Každý rok som v púšti celú zimu. U rolníkov si prenajímam pozemky ked'pre ovce nie je paša v púšti. Ked' je tráva, ideme do púšte a tam som slobodný. Do smrti budem slobodný. Keby som zostal tu a býval $v$ dome, to by bola smrt'. (muž, 60 rokov)

$\mathrm{V}$ súčasnom globalizovanom svete sa $\mathrm{k}$ tejto charakteristike pridružuje viacero iných príznakov, ktoré vytvárajú špecifické skupinové psychické uspôsobenie, na základe ktorého sa samotní beduíni považujú za osobitú arabskú subkultúru. Abú Džabar je pravý beduín. Má ovce a celýživot žije v stane.

3 Abú Džabar si prenajíma pašu pre stádo na okraji dediny od rolníka. Rolník ho upodozrieva zo slabej viery, lebo pravidelne nenavštevuje mešitu. Beduín s ním napokon ide $\mathrm{v}$ piatok na spoločné modlenie. Pravdepodobne ani sám nevie, či sa bojí rolníka, od ktorého je pri dedine závislý, alebo či tam ide kvôli hlbke svojej viery a Bohu.

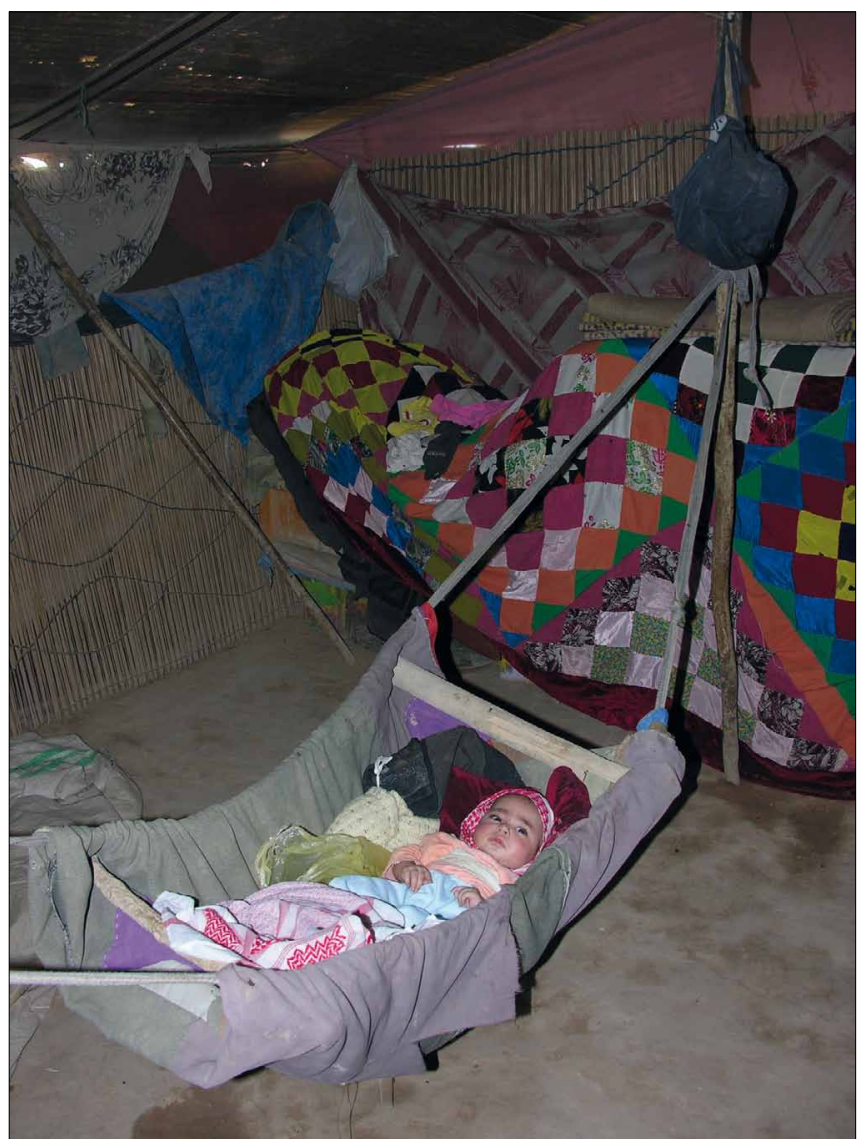

Obr. 5. Kolíska v stane, 2008.

Moji rodičia boli praví beduíni. Mali šestisto oviec a mali len stan. Otec mal tri ženy. Asi sa ožením s druhou ženou, lebo táto je tehotná a deti sú ešte malé. Treba robit', dojit kravy, mlieko predávame... Ja som pôvodom beduín, som pokrokový beduín. Nemám ovce. Zavlažujeme záhradu, mám kravy a bývam $v$ dome. Ale sme pyšni že sme beduíni, lebo sme poctiví a čistí. $V$ meste je falošnost'a nepoctivost'. Nezáleží im na svojom mene. (muž, 38 rokov)

Beduíni sú rovnako vnímaní aj väčšinovým obyvatelstvom arabského sveta. Takéto postoje znamenajú konzervovanie súčasného stavu a vytvárajú bariéru medzi príslušníkmi beduínskej menšiny a majoritou. Okrem vyššie spomenutého obojstranného uznávania beduínov ako pôvodných, „pravých“ Arabov je čoraz evidentnejším príznakom ich osobitosti vo všeobecnosti nižší sociálny status, zvýraznený archaickým nárečím. Stagnácia vývoja jazyka je analogická s inými kultúrnymi parametrami. Dialekt akoby bol charakteristikou a súčastou sociálneho postavenia. Na prvý pohlad zretelný prejav vzájomnosti a indikátor kultúrnej odlišnosti ${ }^{4}$. Pre pravých beduínov - pastierov $\mathrm{z}$ púšte, ale tiež pre pokrokových beduínov - rol'níkov aj chovatelov dobytka na zavlažovaných pozemkoch, ktorí sa identifikujú ako beduíni kvôli beduínskemu pôvodu svojich predkov. $\mathrm{V}$ každom prípade

4 Porovnaj Tesař, F.: $(2007,22$ a n.) 
obojstranne akceptovaný znak, ktorý je potrebné rešpektovat a zachovávat'. Ak ministerský úradník vyrastal v beduínskom stane, beduínom je a zostane. Nejde len o jeho snahu začlenit sa do majoritnej spoločnosti, ale aj o registrovanie jeho beduínskej identity v dedinskom alebo mestskom prostredí. Všetci vedia, že je beduín. Nie je socializovaný v meste. Len si myslí, že základom jeho inakosti je archaický dialekt. V skutočnosti sa ako beduín správa. Dokonca sa aj oblieka ako beduín práve preto, že možno nechce, aby ho ako beduína identifikovali. Stále použiva výrazný parfum, do práce nosí biele ponožky. Neobúvajú si ich beduíni, no už ani jeho kolegovia na pracovisku. Prezrádza ho dokonca aj jeho chôdza podobne ako starú Kysučanku, pristahovanú z vrchov na juhozápad. Aj tá kráča do kostola po rovnej ceste prihnutá, ako keby šliapala do kopca a ešte $\mathrm{k}$ tomu s batohom na chrbte. Ja som $v$ robote oblečený po mestsky ako oni, ale mám aj naše tradičné šaty. To si obliekam len na sviatky, ked'som medzi svojimi. V̌̌etci vedia že som beduín podla toho ako rozprávam. ${ }^{5}$ (muž, 38 rokov) Vysoko postavený úradník na Ministerstve turizmu má rodičov beduínov a sám vyrastal $\mathrm{v}$ stane. Jeho beduínsky pôvod bol zrejmý na prvý pohlad podla výzoru a tetovania ${ }^{6}$ na čele a brade. Som vzdelaný beduín. Aj moje deti sú beduíni, majú beduínsky pôvod. Môj syn je detský lekár v Bonne. Vysoko uznávaný detský špecialista. Je bedu. Jeho deti už nie, lebo si vzal za manželku Nemku. Ja mám manželku z mesta, nikdy mi nepovedala, že sa hanbí vydat'sa za bedu - som vzdelaný. Som pracovitý, dodržím slovo, som pohostinný a priatel'ský. To mám od beduínov. Nikdy som od svojich kolegov nepocitil, že by ma podceňovali. Nehanbím sa, že som beduín. (muž, približne 60 rokov)

$\mathrm{V}$ súčasnosti sa mnohí beduíni kontaktujú s dedinským a mestským obyvatel'stvom ovel’a intenzívnejšie ako kedykol'vek predtým. Aj fyzicky/rezidenčne sú si bližší a pochopitelne si uvedomujú vlastnú identitu. Moji rodičia prišli $z$ púšte a postavili dom. Ja som sa narodil tu a $v$ badii pod stanom som nikdy nebol. Som beduín, je to môj pôvod. Beduíni budú aj naše deti aj ich deti aj ich deti. Bedu zostane bedu. Ja som

5 V meste/zamestnaní je prejavom identity predovšetkým archaický jazyk. Možno ho považovat za prirodzený indikátor identity. Skupinová príslušnost' beduína $\mathrm{v}$ meste nijako nediskredituje, preto sa ani nesnaží svoju identitu zakrývat. Verbálne vyzdvihuje svoje cenné beduínske vlastnosti, no niekedy ide s kolegami na pivo, čo by ho vo vlastnej komunite vystavilo na okraj spoločnosti. $V$ domácom prostredí sa beduín vedome snaží manifestovat svoje vyššie spoločenské postavenie.

6 Staršie beduínky vo veku približne nad 60 rokov majú väčšinou tetovanie na tvári. Ako malé $5-7$ ročné dievčatá ich pre krásu tetovali staršie sestry alebo cigánky. Niektoré ženy majú výrazné obrazce na podstatnej časti tvári, alebo len bodku na čele, nose alebo líci, na jednej alebo oboch rukách. Muži si dávali tetovat na tvár bodku, na ruky vlastné meno alebo rôzne obrazce na viditelnom mieste alebo pod odevom. Tetovanie môže byt aj dôsledkom liečenia - hrčku na ruke alebo inej časti tela odstraňovali pichaním horúcou ihlou namočenou do soli a dezinfekčného roztoku. Vo všeobecnosti viac príslušníkov strednej generácie už tetovanie nemá. U súčasných školopovinných detí sme tetovanie nezaregistrovali. bedu. Od ostatných z mesta alebo od rolníkov nás odlišuje pocit. Cítim, že sme bedu. Nič iné, ale vieme, že sme bedu. Aj manželka je bedu. Máme doma meč, koberce v madafe, sedlo $z$ t’avy. Priatelia $v$ meste ma nevolajú menom, ale beduín. (muž, 46 rokov) ... Ja som rolník. Nemôžem povedat', že som beduín, lebo nie som. Moji rodičia aj prastarí rodičia boli rolníci. Pôvodne boli všetci Arabi beduíni. Aj teraz mnohí prichádzajú z púšte a zostávajú v dedinách. Chovajú kravy, obrábajú pôdu a žijú $v$ domoch ako ja. Ale sú beduíni. To záleži od človeka. Kto sa narodil ako beduin a kto cíti že je beduín, ten je beduín. Nemusí bývat' pod stanom a hladat's ovcami trávu. Srdce a hlava človeka povedia, čo je. (muž, 66 rokov)

Dedinskí rolníci aj beduíni dokážu bez dlhšieho uvažovania vymenovat viacero medziskupinových kultúrno- diferenciačných príznakov. Vyjadrenia majú na oboch stranách len konštatačný charakter bez snahy kladne alebo záporne hodnotit: bedu sú tmavší ako dedinčania; bedu sú podstatne skromnejší v stravovaní aj v bývaní; bedu sú velmi otužilí, aj malé deti chodia bosé alebo v sandáloch bez ponožiek ${ }^{7}$; beduín si vie postavit’ stan a žit v ňom celý život, to dedinčan nevie; ked' dedinčan pasie, má menší stan, beduín má všetko so sebou; bedu sú velmi čistotní, každý deň perú a chodia v čistom; beduín neprejde okolo človeka bez pozdravu'; bedu používajú maslo a dedinčania olivový olej; bedu varia vo väčších množstvách; bedu jedia $\mathrm{z}$ väčších mís; dedinčania jedia viac zeleniny; bedu dajú hostovi všetko naraz a dedinčania prinášajú postupne; bedu ženy majú na hlave spodnú šambor a vrchnú mandíl sús, dedinčanky nosia len jednu šatku; bedu dievčatá nosia vždy šatku a dedinské majú dlhšie vlasy; dedinčanky nosia na šatách zásteru - kebút, beduínky len dlhé šaty; dedinčania majú menšie madafy ako beduíni a v obývačke stôl a stoličky; rolnícki chlapci nenosia dlhé habaje; bedu robia svadby okolo stanu a dedinčania si prenajímajú sály; bedu muži aj ženy tancujú spolu, dedinčania muži a ženy osobitne; dedinčania majú niektoré slová iné, napríklad baran.

7 Snaha nebyt horší ako majoritné dedinské a mestské obyvatel'stvo sa prejavuje napríklad aj v nosení ponožiek. Ak mladý beduín býva $\mathrm{v}$ stane a odtial dochádza do zamestnania, hoci len ako robotník do fabriky, obúva si do topánok ponožky. Ak nejde do práce, v stane a pri akýchkolvek každodenných spoločenských a ekonomických aktivitách chodí naboso. Pre vzdelaného beduína zamestnaného v štátnej správe sú práve ponožky neraz symbolom jeho vyššieho statusu a patrí sa, aby si ich nezobúval ani medzi svojimi. Ponožky nosí denne aj šejk na každej úrovni. Podobne aj hlava rodiny, lebo často prichádza na šálku kávy a vybavovat najrôznejšie spoločenské aj ekonomické záležitosti nie len do beduínskych stanov, ale aj k rolníkom. Pri vstupe do madafy sa každý zobúva a ak by bol beduín naboso, mohlo by to pre neho znamenat určitú ponižujúcu pozíciu, respektíve negatívnu odlišnost'. Nie je dôležité, že sú ponožky deravé.

8 Ak dieta nepozdraví susedov, dohovárajú jeho rodičom. Rodičia učia deti, že pozdrav je prejavom úcty. Ak sa dospelý ženatý syn vracia z práce, po vstupe do stanu bozká dvakrát matke ruku a bozká ju aj na čelo, otcovi bozkáva ruku tiež dvakrát. Beduíni nemajú radi pozdrav Marchabá. „Marchabá nie je arabské, tak sa zdravia v meste. As salám - to nie je len pozdrav pre Teba, ale aj pre Boha“. (muž, 60 rokov) 


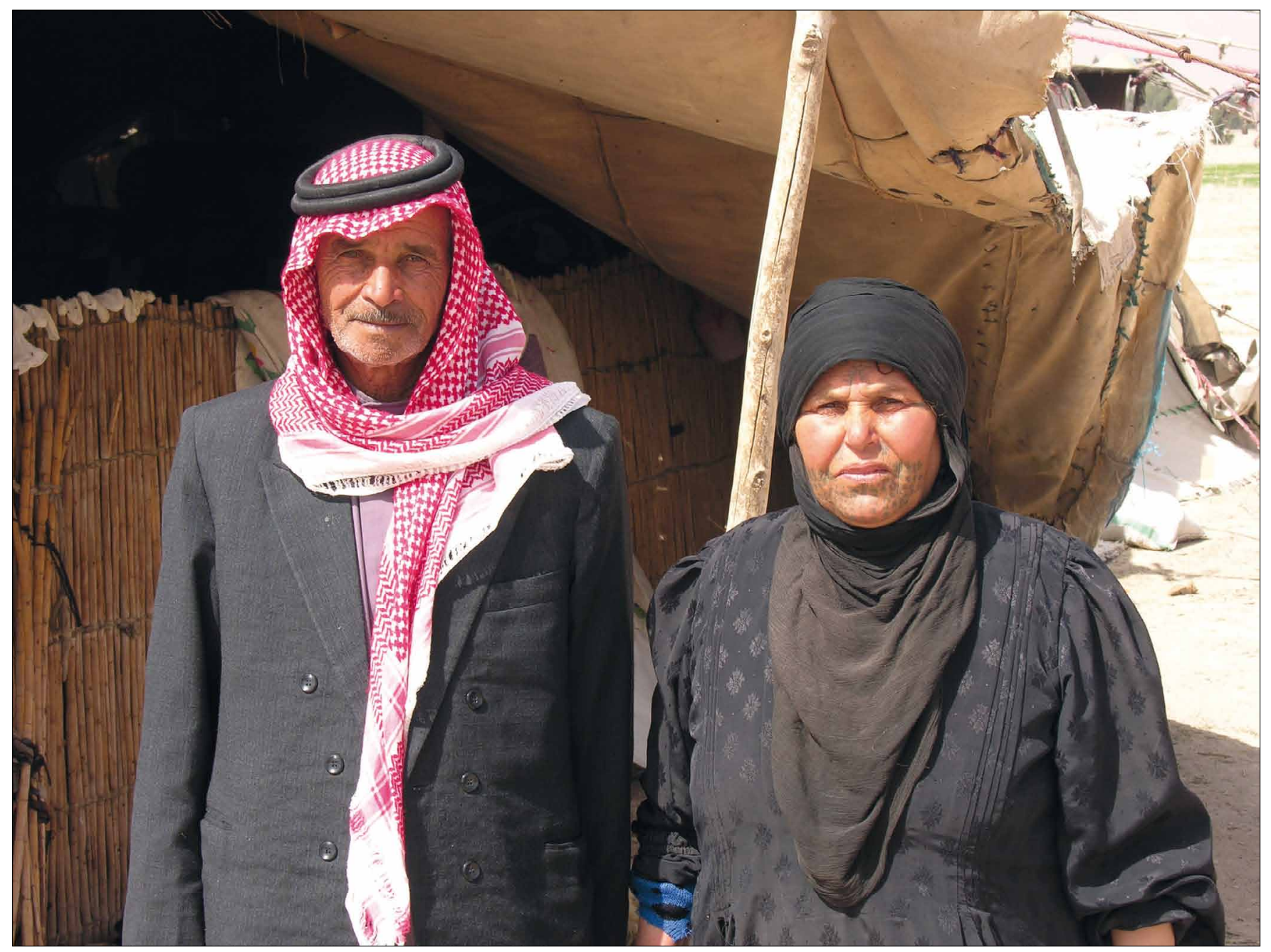

Obr. 6. Rodičia, 2008

Podobné diferencie možno nájst’ aj medzi beduínmi a mestským obyvatel'stvom. Je zaujímavé, že ludia $\mathrm{z}$ mesta beduínov neodsudzujú, len ich rešpektujú. Pri priamom medziosobnom kontakte si však uvedomujú vlastný vyšší ekonomický aj intelektuálny status (myslišs si, že potrebujem, aby o mne ludia povedali, že som sa vydala za nejakého beduína? - povedala žena z Damasku, ked' jej obchodník - beduín navrhol po siedmich rokoch spoločného života úradne legalizovat' manželstvo) a tažký kočovný spôsob života $\mathrm{v}$ stane im vlastne zazlievajú (ked' tak žijú, nemajú v hlave všetko v poriadku obchodník z mesta).

Názory na beduínov sú rôzne, lebo také sú aj osobné skúsenosti príslušníkov majority s kočovníkmi. Mnohí netušia, že čast' z nich už žije usadlým spôsobom života, niektorí sa stali prezidentmi arabských štátov, v samotnej Sýrii majú zastúpenie v parlamente. Poznal som bedu na vojne. Boli slušní, poslušní, skromní, nelísili sa od ostatných. Nevedeli sa zapojit do kolektívnych športov, ale nemali konkurenciu v behoch od 1000 do 3000 metrov. Každú príležitost'využívali na vzájomné posedenia. Rozprávali sa o púšti a o ovciach. Kde práve sú ich rodičia, čo asi ro- bia. Nemali záujem o krátke vychádzky, ale chceli volno na viac ako štyri dni, aby mohli nájst' svoju ašíru. (muž, 48 rokov)

Usadlí beduíni sa navzájom výrazne odlišujú svojimi názormi a správaním $\mathrm{v}$ závislosti od stupňa spútanosti s tradíciou. $\mathrm{V}$ mnohých murovaných madafach, podobne ako v stanoch, sa vedú dlhé rozhovory o tom, či hostitel' v konkrétnom prípade urobil, alebo neurobil pri stolovaní chybu (či mal jedlo priniest' sám alebo to nechat na synov, či mali, alebo nemali byt' synovia pri prinášaní jedla bosí, komu mala byt vzdaná najväčšia pocta - pred kým mala byt misa s hlavou barana...), čo hostom nemal povedat', čo mal povedat' a urobit rozhodne ináč. Riešenie uvedených aj mnohých iných, zdanlivo nepodstatných, akoby detinských problémov, neustále konfrontovanie súčasnosti s kultúrnymi vzormi, možno považovat za dôležitú kultúrnu charakteristiku beduínov.

Beduíni sa považujú za lepších, povolaných hodnotit', kritizovat' a poúčat', chránia si svoju identitu - obyvatelom mesta vyčítajú predovšetkým príklon ku konzumnému euroamerickému životnému štýlu a najmä nedostatočnú vieru a pokoru pred Bohom: 


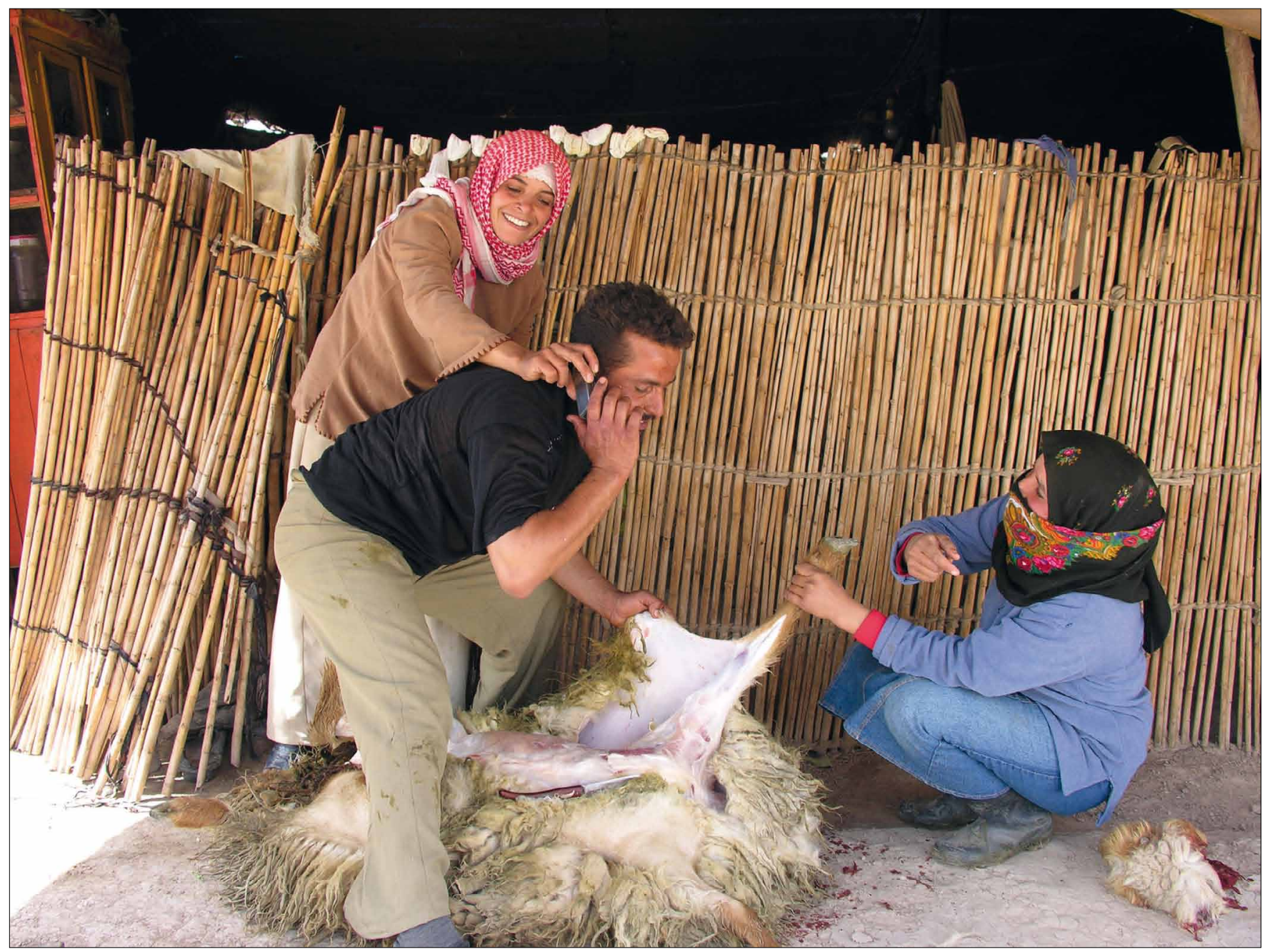

Obr. 7. Dôležitý rozhovor, 2008.

ludia $\mathrm{v}$ meste sú zlí - sedia $\mathrm{v}$ reštauráciách a pijú pivo aj alkohol; beduín ide len tou cestou, ktorou príde za svojou prácou, v meste chodia kdekolvek; bedu každému pomôže, je pohostinný a štedrý; bedu fajčia cigarety a ludia v meste argille, lebo sú pri stole a na vodnú fajku majú čas; bedu sú menej kultúrnejší ako v meste, deti nejdú na disko, je to proti islamu. Beduíni uzatvárajú endogamné manželstvá v rámci vlastnej skupiny a takmer výlučne $\mathrm{v}$ najužšom príbuzenstve. V konečnom dôsledku to znamená konzervovanie nárečia a prirodzenú bariéru - vo všeobecnosti nízky stupeň včleňovania externých kultúrnych vplyvov, ktoré by výraznejšie narušili podstatu a celistvost' vlastného kultúrneho systému a beduínsku identitu. Akulturácia bezpochyby prebieha, no dávkovanie je citlivé, selektívne mechanizmy nedovolujú prekročit únosnú mieru. Dovolujú modifikácie, no nie zásadnú zmenu. $\mathrm{V}$ prvom desatročí 21 . storočia existujú rôzne úrovne beduínov, odvíjajúce sa od ich relevantných ekonomických aktivít a s nimi súvisiaceho spôsobu života: „praví“ Arabi, ktorí majú svoje stádo a kočujú; rolníci; chovatelia dobytka; remeselníci; železničiari; priemyselní robotníci; obchodníci; úradníci; lekári; učitelia; právnici. Vzdelanostná úroveň a profesijná orientácia znamená vel'ké sociálne a kultúrne diferencie. Pozostatkom tradičnej materiálnej kultúry usadlých beduínov je spravidla niekolko artefaktov, ktoré zväčša zmenili funkciu $\mathrm{z}$ úžitkovej na dekoratívnu. Ked'rodičia prestali chodit's ovcami do púšte, všetko predali a kúpili pozemky. Mám len meh-baš $v$ madafe, kde prijímam hostí. Ten nedám nikomu. (muž, 50 rokov

Po prechode od nomádizmu k stálym obydliam sa $\mathrm{z}$ tradičných kultúrnych hodnôt ako prvé vytrácajú prvky materiálnej kultúry. V takomto kontexte madafu nemožno považovat' za súčast' kategórie materiálno - technologickej, skôr spoločensko - organizačnej. Slúži na prerokovávanie najvýznamnejších rodinných záležitostí, je stále otvorená - prijímajú sa tu hostia. V určitom slova zmysle je symbolom priatel'stva, pohostinnosti a štedrosti ako čŕt beduínskej identity. Ale rozhodne je aj prostriedkom dokazovania beduínskej identity. Som beduín. Predávam zeleninu v meste a moja manželka tiež chodí do roboty. Ovce a stan nemám a taký neistý život by som už nechcel. Bývam v dome a na dvore mám madafu. Môžem tam kúrit' a pozerat televízor. Každý deň sme tam, pijeme kávu a rozprávame sa. (muž, 53 rokov) 
V duchovnej sfére sa u bývalých kočujúcich beduínov dodnes zachovalo najmä vedomie skupinovej príslušnosti. Napriek odlišnému ekonomickému zázemiu sa všetci identifikujú ako beduíni. Len $\mathrm{v}$ jednom prípade sme zaregistrovali, že by identitu zapreli, alebo sa od nej akokolvek dištancovali'. Naopak cítia ju ako svoju prednost. Ja som bedu a zomriem ako bedu. Do púšte by som sa už nevrátil a ovce by som nechoval. Mám kravy, pozemky a to je jednoduchšie ako pást'. (muž, 43 rokov) Beduínska identita je manažovaná mimoriadne efektívne. Založená je na vedomí vlastnej totožnosti a jedinečnosti na úrovni jednotlivca aj skupiny a zároveň zretelnej, všeobecne akceptovanej a neustále pripomínanej/zdôrazňovanej diferentnosti. Jej sila spočíva aj v množstve determinujúcich faktorov/kontextov, ktoré ju stmelujú a zároveň zvýrazňujú osobitost' a akceptabilitu. Súhrn kontextov, kultúrnych osobitostí, je vysoko cenený ako celok. Práve v ňom treba vidiet určujúci faktor obojstranne vnímanej polarizácie a akceptovanej identity. Kvôli kultúrnym špecifikám je identita beduínov prezentovaná obidvomi stranami ako kladný vzor, príklad žiadaného občianskeho, náboženského, ekonomického, morálneho. Princíp aj protikladnost identít minority a majority sú prekvapujúce $\mathrm{v}$ tom, že základom polarizácie a príkladom pre väčšinu je kultúrny komplex minority. Od neho je odvodená jej identita - a tým vlastne aj identita majority. Je však evidentné, že takto profilovaná identita nie je umelým konštruktom, ale je „čítaná“ zo spôsobu života a z kultúrnej reality jej nositelov bez snahy dosiahnut akýkolvek prospech. Napriek takémuto konštatovaniu sa nám predsa len javí, že $\mathrm{v}$ niektorých prípadoch je identifikácia beduínov účelová. Ak nemá ekonomický, vecný ani praktický základ, dokonca ani čisto emocionálny, človek sa snaží dokázat svoju inakost možno len preto, aby bol niečím zaujímavý. Podla okolností zvýrazňuje v majoritnom prostredí svoju minoritnú príslušnost’ a doma poukazuje na väzby s majoritou. $\mathrm{K}$ zložitosti situácie prispieva aj poznanie, že kým identita/vyčleňovanie beduínov príslušníkmi majoritnej spoločnosti je projektovaná ako odraz reality, mladí, no autoritatívnymi princípmi a tradíciami spútaní beduíni ju chápu ako kultúrne dedičstvo, ktoré je nutné zachovávat aj za cenu strádania, utrpenia, obetovania sa. Povinnost voči živým aj mŕtvym autoritám. Človek by išiel za lepším. $V$ dome sa lepšie býva. Ale my sme beduíni, máme ovce, tak na to nemôžeme mysliet'. Náš život je takýto. Z oviec žijeme. (muž, 21 rokov)

9 Starosta dediny pri meste Douma vo veku približne 35 rokov sa narodil $\mathrm{v}$ rodine beduínov, ktorí sa usadili $\mathrm{v}$ dedine pred jeho narodením. Sám nikdy nebol v púšti a nespal v stane. Študoval v rodnej dedine, v krajskom meste aj v Damasku. Je štátny zamestnanec, nemá pôdu ani dobytok. Podla neho už nie sú odlišnosti medzi usadlými bedu a rolníkmi a netreba o nich hovorit ako o beduínoch, lebo beduíni sú kočovníci. Títo už nekočujú, nie sú teda beduíni. Sú pokrokoví dedinčania. Napríklad beduínske ženy sú pracovitejšie a pružnejšie ako staré dedinčanky. Tie sú naučené byt doma, beduínky sú naučené viac sa starat’ a odchádzat’ $\mathrm{z}$ domu za prácou. Starostovi je nepríjemné hovorit o beduínoch a o svojom pôvode. Manželku má z Damasku, evidentne by sa ho dotklo, keby ho niekto označil za beduína.

\section{EKONOMICKÉ AKTIVITY}

Základným determinantom spôsobu života a kultúry beduínov sú ekonomické aktivity, vyplývajúce z vlastnenia stáda a kočovného pastierstva. K prežitiu však boli vždy potrebné aj doplnkové zárobkové aktivity. Súviseli s obojstranne prospešnou koexistenciou s rolníkmi a s obchodovaním - nákupom lacnejšieho tovaru, jeho prevozom púštou na tavách a predajom so ziskom.

Beduíni v Sýrskej púšti z vlastnej skúsenosti, respektíve mladší z rozprávania rodičov vedia, že pôvodne žili v púšti len so stádami tiav, bez oviec. Ešte v polovici 20. storočia mali niektorí beduíni 50-60 tiav a žiadne kozy ani ovce. Väčšinou však vlastnili 14-20 tiav kvôli obchodu a stádo oviec.

\section{Ťava}

V beduínskej ekonomike mala tava ešte pred niekolkými desatročiami špeciálnu pozíciu, neporovnatelnú s ovcou. Ťavy rozmnožovali a chovali, aby ich využívali na prenášanie nákladov, predávali ich na mäso, využívali kožu, srsț, trus, pili mlieko. Do polovice 60. rokov 20. storočia mala tava hodnotu ako 10 baranov. $\mathrm{S}$ tavami v púšti bol diametrálne odlišný model hospodárenia aj spôsobu života. Ťava dospieva ako štvorročná, máva len jedno mláda. Počet samcov a samíc bol približne rovnaký. Mladé tavy nepredávali, len samcov a staré samice vo veku približne 30 rokov. Ak pri významnej príležitosti tavu zarezali, čast mäsa pokrájali na dlhé úzke pásy, zasypali solou a sušili na slnku. Vysušené odkladali zakrútené do plátna. Surové mäso sa dodnes akoby nezištne rozdáva susedom, no princípom je očakávanie reciprocity. Ťavy žijú v tažkých podmienkach. Sú vytrvalé, smelé, aktívne a podobný účinok vyvoláva aj tavie mäso. Je považované za kvalitnejšie, výživnejšie a zdraviu prospešnejšie ako baranina. $\mathrm{V}$ posledných rokoch chovajú tavy len v minimálnom rozsahu a tavie mäso konzumujú výnimočne. Každý vie, že kilogram baraniny stojí 300 lír, no cenu tavieho mäsa pozná prakticky len ten, kto vlastní tavy a predáva ich. Ťavy dojili starší muži a zvierata sa nedotýkali pravou rukou. Ťava je dost nevyspytatelná a prijatel’nejšie bolo, ak pohrýzla lavú ruku. Od jednej nadojili denne 10 kilogramov mlieka. Ak mali beduíni popri tavách aj ovce a kozy, tavie mlieko $s$ iným nemiešali. Slúžilo len na pitie v surovom stave. Podla koránu sa nemá tepelne upravovat a akokolvek spracovávat'. Nevyrábali z neho preto syr ani maslo. Jedinými pokrmami boli často datle a mlieko. Ak žena nemohla kojit', kojencom nedávali pit silné tavie mlieko, ale kozie. Pôvodne tavie mlieko nebolo ekonomickou komoditou, no v súčasnosti je pre svoje priaznivé účinky na zrak, sexuálnu aktivitu, liečenie alergií a rakoviny vyhladávané a stalo sa zaujímavým obchodným artiklom. Beduíni ho najradšej nechávajú pre mláda, aby rýchlo rástlo. Ťavy strihali vždy v máji. Srstou napchávali matrace, $\mathrm{z}$ priadze tkali plachty na stany, prikrývky. Koberce tkali z miešanej priadze $\mathrm{z}$ tavej a ovčej vlny. Príslušníci kmeňa vlastnili niekolko krosien, ktoré si podla potreby požičiavali. Tkanina mala len prirodzenú hnedú farbu, lebo priadzu ani tkaninu nesmeli na základe súry v koráne farbit. 
Aby dosiahli farebný dekor, kombinovali taviu a koziu srst'. Z priadze plietli ponožky. Ak chceli hustú tkaninu na vrchné oblečenie proti zime a daždu, dávali si ju tkat dedinčanom, sami nepoznali technológiu. $Z$ vysušenej a jednoducho opracovanej kože vyrábali podrážky na topánky, šili sandále, alebo ju vystierali na podlahu ako podložku.

Ráno je pri tave asi 5 kilogramov trusu. Pozbierali ho do kusa látky a vysušili na slnku. Vysušený je čierny, lesklý, vo vel'kosti orechov. Plnili ho do vreciek a uskladňovali medzi vonkajšiu stenu stanu a vnútornú trstinovú stienku. Slúžil na kúrenie, považujú ho za najlepšie palivo.

Kým neexistovala povinná školská dochádzka a vojenská služba, muži si vlasy nestrihali. Mali ich dlhé až po pás. Zapletali si vrkoče - po tri na obidve strany a nosili ich vpredu. Na hlave bola šatka a ogal. Starší boli takto upravení ešte na konci 70. rokov 20. storočia. Muži i ženy si raz týždenne umyli vlasy tavím močom. Nevypadávali, vydržali celý týždeň tvrdé s gaštanovohnedým odtieňom. Nebol žiadny problém získat túto tekutinu, lebo tava súvisle močí až 15 minút.

$\mathrm{V}$ súčasnosti len zriedka vidno beduína s nitou $\mathrm{z}$ tavej srsti uviazanou okolo zápästia. Ešte pred pár desatročiami bol tento jav všeobecne rozšírený, lebo sa verilo, že tavia srst' pri bolesti ruky vytiahne chorobu. Spôsobuje zvláštnu teplotu, vyvoláva príjemný pocit. $Z$ ruky sa nemusí snímat ani pri umývaní, lebo nenasáva vodu ${ }^{10}$.

\section{Beduíni a rolníci}

Rolníci beduínov vždy potrebovali, lebo sami nemali tavy. $\mathrm{V}$ dedinách chovali bežne kone, no nie do záprahu, len na oranie a jazdenie. Nezapriahali ani kravy, chovali ich výlučne na dojenie ${ }^{11}$. Rolníci potrebovali beduínov, aby im požaté obilie priviezli na tavách $\mathrm{z}$ pola do dediny $\mathrm{k}$ mlátačke. Po vymlátení odviezli obilie aj slamu do hospodárskych dvorov. Ťavy prenášali náklad na dlhých nosidlách s dreveným rámom. Za vykonanú prácu beduíni dostávali dohodnuté naturálie ${ }^{12}$. Vítané bolo obilie, ale rovnako aj drevo na kúrenie. Rolníci sa s tými istými beduínmi kontaktovali dlhé roky a hned' po mlatbe obyčajne dohodli spoluprácu aj pre budúci rok. Rolník zabil baranov, pohostil beduína aj svojich susedov. Mlatba a dožinková hostina al- žorá sú len jednými

10 Bez tavy sa nezaobišla svadobná burza. Bola to všeobecne očakávaná čast' svadobných obyčají, kedy mali ženích s nevestou prvýkrát povolený intímny styk. Ženícha niesli do špeciálne pripraveného ohradeného priestoru na odlahlom mieste „svadobnej noci“ mládenci na ramenách a prehodili ho dovnútra, nevestu vyložili na vyzdobenú tavu a do burzy (termín burza znamená samotný obrad aj miesto uskutočnenia obradu) ju odviedla matka.

11 V roku 1948 prišli do Sýrie utečenci z Palestíny a priviedli kravy. Volajú sa golanské kravy. Dovtedy chovali v dedinách kravy len zriedka. Beduíni sa začali preorientovávat na usadlý spôsob života a chov kráv namiesto nomádneho ovčiarstva postupne od 70. rokov 20. storočia.

12 V súčasnosti je naturálna výmena zriedkavá. Za prácu, služby a tovary sa platí ihned' a v hotovosti. z mnohých príkladov obojstranne prospešnej kooperácie a tradičných ekonomických a spoločenských kontaktov nomádov a rolníckeho obyvatelstva. Beduíni predávali rolníkom baranov a niekedy aj tavy na mäso ${ }^{13}$. Od rolníkov kupovali figy, sladké pečivo $\mathrm{z}$ datlí, drevo a viničné prúty na kúrenie. Beduíni si čast' nechali pre svoju potrebu, čast' speňažili $\mathrm{v}$ meste na trhu. Remeselníkom si dávali šit’ obuv, tkat a šit habaje. Aj preto nosili beduíni a rolníci v dedinách na okraji púšte podobné oblečenie. Rolníci boli k beduínom vždy štedrí. Na ich pohostenie minuli vela peňazí a často im požičiavali hotovost'. Nebáli sa, že požičané nedostanú spät. Kde žijú beduíni a rolníci v susedstve, dodnes udržiavajú rôzne obojstranne prospešné pravidelné, príležitostné, respektíve náhodné kontakty. Rolník vezme úrodu a ovce beduínov mu vyčistia polia od zvyškov bylí, koreňov a buriny, ktoré by sa v pôde nestačili rozložit', lebo okamžite sa zakladá nová úroda. Urobia mu tak osoh. Za prenájom získava pravidelne peniaze, ovce mu pohnoja pozemky. Početné beduínske rodiny znamenajú pre rolníkov námezdnú pracovnú silu v polnohospodárstve. Okrem spomenutých pozemkov na pasenie kupujú trávu pre kŕmne barany, ktoré sú určené na predaj, pre ovce s jahňatami a jahňatá, ktoré ešte nie sú schopné íst na pašu. Kvôli beduínom tak rolníci pestujú trávu. Ak má beduín v stáde približne 450 kusov oviec, prenajíma si 2,5 ha trávy, jednu úrodu z 10 árov po 3000 lír. Do roka berú postupne štyri úrody, čo predstavuje len za prenájom

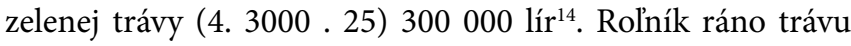
pokosí a beduíni (dospelé deti a nevesty) ju ručne - bez hrablí a vidiel pozhŕnajú, pozberajú, na plachte v dvojiciach ponosia $\mathrm{k}$ autu a dovezú domov (podla dohodnutého množstva nakosenej trávy každý druhý, alebo každý tretí deň). Rolníci predávajú beduínom drevo na kúrenie, poskytujú im pitnú vodu. Vzájomne sa pozývajú na hostiny pri významných rodinných udalostiach. Koexistencia s rol'níkmi znamená pre beduínov príležitost' zoznamovat' sa s usadlým spôsobom života a neocenitel'nú možnost' získavat' pracovné návyky, skúsenosti a zručnosti v maštalnom chove dobytka a rolníctve od kyprenia pôdy a zavlažovania až po zber úrody. Všetky technológie vidia alebo sa ich aktívne zúčastňujú ako nádenníci.

\section{Obchod}

Ešte začiatkom 70. rokov minulého storočia sa beduíni zaoberali hlavne obchodom. 10-15 členné skupiny mužov približne so sto tavami sa vydali spravidla dvakrát v zime a štyrikrát v lete do Jordánska, Saudskej Arábie, Bagdadu alebo až do Emirátov po tovar. Rozhodujúce bolo, kde sa práve dalo lacnejšie nakúpit. Cestou tam neviezli nič. Zastavovali sa, aby sa najedli a napojili tavy. Tým stačilo pit’ raz za tri dni. Niektorí viedli tavy, iní cestou v sedle spali. V hraničnej Aradbe, Ománe alebo v inom cielovom mieste, kde putovali

13 Situácia sa v súčasnosti mení - rolníci začínajú chovat tavy na mäso a beduíni si ho spravidla nemôžu dovolit’ kúpit'.

14 Ak doja 150 dní a denne predajú 30 kg syra po 120 lír, z mlieka získajú ročne 540000 lír. 


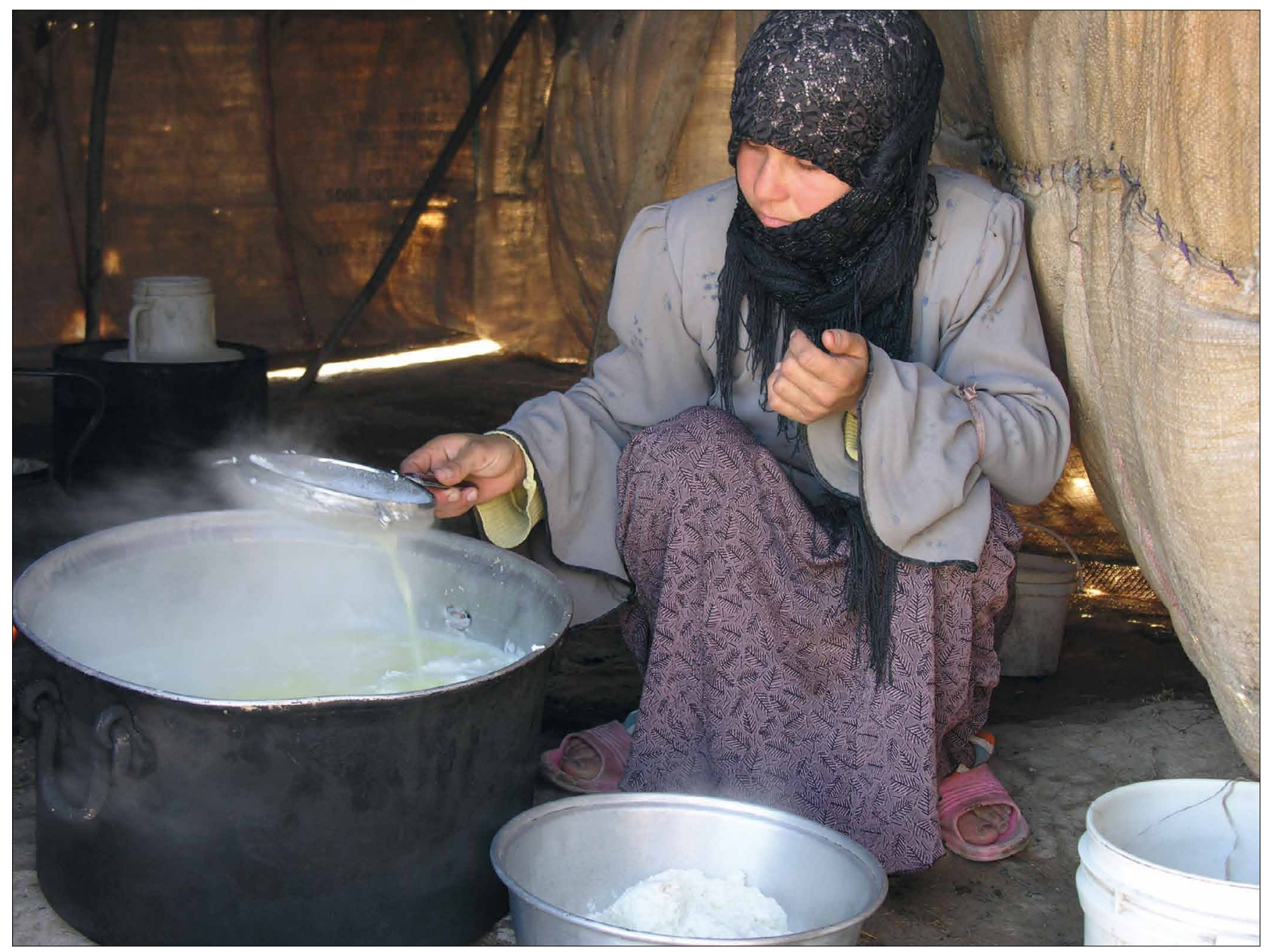

Obr. 8. Nevesta v kuchyni, 2008.

od troch do štrnástich dní, ich už čakali obchodníci s tovarom. Nakúpili, naložili aj krmivo pre tavy, zdržali sa 1-2 dni a vydali sa na spiatočnú cestu. Ideálne bolo, ak cesta tam aj spät netrvala dlhšie ako týždeň, potom sa už na ludoch začala prejavovat únava. Na každú tavu naložili aj 300 kilogramov tovaru - cukor, sol', šatky, v Iraku a Emirátoch datle a čo bolo pre priekupníctvo aktuálne najvýhodnejšie. Miestnym obchodníkom tovar predali až s 50\% ziskom, čo znamenalo pre podnikavých beduínov značný finančný efekt. Ak to bolo práve výhodné, predávali v Damasku alebo až $\mathrm{v}$ Istanbule.

\section{Ovce}

Ovce začali zaháňat do púšte obchodníci z Damasku a beduíni im ich pásli za $25 \%$ podiel zo zisku. Postupne redukovali počet tiav a zabezpečovali si aj vlastné stáda oviec. V púšti sú ale dodnes závislí od obchodníkov, ktorí žijú počas sezóny dojenia popri nich, kupujú od beduínov spravidla dennú produkciu mlieka, vo vlastnej réžii vyrábajú syr a vozia ho obchodníkom do miest vzdialených aj stovky kilometrov ${ }^{15}$. Beduíni si nechávajú mlieko len pre vlastnú potrebu. Vyrábajú si syr, maslo, prevarené maslo ${ }^{16}$ a jogurt. Posledných $10-$ 15 rokov už používajú len umelé syridlo. Syr aj sušia a odkladajú ho na sezónu ked' sa nedojí - suchý syr rozrábajú s vodou

15 Mlieko nemerajú na litre, ale vážia na kilogramy. 20 litrov mlieka váži 17 kilogramov. Sú nádoby - mierky s vyznačenou hmotnostou. Obchodníci z okolia Alepa majú v púšti svojich zamestnancov vo viacerých stanoch, kde bývajú, vykupujú a spracovávajú mlieko. Ked' je dobrá paša, denne vyrobia aj $1500 \mathrm{~kg}$ syra a každé dva dni ho odvážajú do vzdialenosti stoviek kilometrov a predávajú s velkým ziskom. Zo $100 \mathrm{~kg}$ mlieka sú beduíni schopní vyrobit približne 30 kg syra, obchodníci majú kvalitné umelé syridlá a dosahujú 40 až $60 \mathrm{~kg}$ syra. Beduíni pri výrobe syra miešajú ovčie mlieko s kozím, obchodníci vykupujú kozie zvlášt̃. Získat pravdivé údaje o hospodárení od beduína je tažké, lebo nechce, aby mu závideli a priamej odpovedi sa vyhýba. Určite vie, kolko syra dnes predal, kolko má jahniat, ale povie - kolko Boh dal.

16 Používajú ho na prípravu jedál, ale napríklad pri zápale hrdla a dýchacích ciest ho ako liek pridávajú do kávy. 
a vyrábajú si laban. Ak sú beduíni v lete so stádom v blízkosti rolníckych obydlí a využívajú prenajaté polia, predlžuje sa doba dojenia, lepšie dokážu speňažit mlieko, vlnu aj živé zvieratá. V púšti predávajú kilogram mlieka za 30 lír a lacnejšie, obyčajne za 25 lír, v meste, respektíve v jeho blízkosti za 35 lír. ${ }^{17}$ Pri stredne vel'kom stáde - približne 450 dojných oviec, od ktorých sa denne počas 100 dní získa po 300 kilogramov mlieka, predstavuje rozdiel príjmu v púšti $(30000 \mathrm{~kg}$ x 25 lír $=750000)$ a pri predaji v meste $(30000 \mathrm{~kg}$ x 35 lír = 1.050000 lír) len za mlieko približne 300000 lír. Od jednej ovce sa strihaním získa priemerne $2,5 \mathrm{~kg}$ vlny. $\mathrm{V}$ meste ju možno predat po 40 lír za kilogram, v púšti ju priekupníci vykúpia niekedy len po 12 lír za kilogram. Pri stáde o celkovom počte 1000 kusov môže rozdiel finančného prínosu za vlnu predstavovat' $100000-30000=70000$ lír. Podobne pri predaji 200 baranov po 10000 , respektíve len po 5000 lír, môže vzniknút finančný rozdiel až 1 milión lír. Toto si mnohí beduíni uvedomujú a racionálne obmedzujú, alebo celkom rušia pobyt so stádami $\mathrm{v}$ púšti, ktorá $\mathrm{v}$ posledných rokoch ovela častejšie neposkytuje dostatok trávy. Radšej platia rolníkom za prenájom pozemkov na pasenie, no šetria na krmive - $\mathrm{v}$ púšti treba ovce dokrmovat a platit priemerne 10 lír za kilogram krmiva (šrot, posekaná slama, mandlové šupy). $\mathrm{V}$ závislosti od velkosti stáda to môže ročne predstavovat niekolko miliónov lír, znamenat aj podstatné ekonomické pasívum a zadíženie kočovníkov - tradicionalistov $^{18}$. V suchých rokoch 1999-2004 mnohí beduíni práve kvôli vysokým nákladom na krmivá podstatne redukovali stáda. Pri prekonávaní väčších vzdialeností je v púšti drahší dovoz vody. Sú to každodenné vysoké náklady, lebo ovca vypije denne asi 10 litrov. V blízkosti rolníckych a mestských sídel beduíni sami spracovávajú mlieko a vyrábajú aj predávajú syr vo vlastnej réžii. Niektorí zo synov dochádzajú sezónne alebo aj trvalo do práce v priemysle, slobodné dcéry majú možnost pracovat ako námezdné robotníčky najmä pri pestovaní zeleniny. Vzhladom na súvislé obdobie vegetácie sú zárobkové príležitosti v tejto sfére prakticky neprerušené s výnimkou významných moslimských sviatkov. Okrem finančného efektu ${ }^{19}$ znamenajú pravidelný prísun zeleniny, v púšsi obyčajne nedostupnej, a pestrejš́ jedálny lístok. V blízkosti vidieckych a mestských sídel je neporovnatelne

17 Kilogram ovčieho mlieka stojí 35 lír, kravského 20 lír. Kilogram ovčieho syra je za 125 lír, kravského za 98 lír. Zo 100 kg kravského mlieka sa vyrobí maximálne $22-26 \mathrm{~kg}$ syra.

18 Aj v 70. - 80. rokoch sa prihodilo, hoci zriedka, že bolo sucho, prípadne zelený porast $\mathrm{v}$ púšti spálil mráz skôr ako stihol vyrást' a beduíni vyhladávali pašu pre stáda $\mathrm{v}$ rozlahlých púštnych oblastiach na severovýchode alebo na prenajatých pozemkoch u rolníkov v dedinách na okraji púšte.

19 Pri oberaní papriky, vyrezávaní karfiolu a iných prácach predstavuje hodinový zárobok 25 lír. Denne pracujú 10 hodín, podla potreby aj dlhšie. Všetky zarobené peniaze dávajú slobodné dcéry aj ženatí synovia otcovi. Dievča si za mesiac môže zarobit' na nové oblečenie (okolo 5000 lír). Ak by dve dcéry odrobili po 300 dní, zarobili by $2 \times 75000$ lír - presne tolko beduín zaplatí za prenájom pozemkov na pasenie 350 oviec v letnej sezóne. bohatší jedálny lístok aj kvôli vyššej intenzite návštev obchodov s potravinami. $Z$ púšte ide do obchodu muž len raz mesačne a obchádza aj susedov, aby zistil, čo potrebujú.

Tesná spätost s prírodným prostredím najmä v posledných klimaticky nepriaznivých rokoch objektívne výraznejšie determinuje zhoršujúcu sa úroveň ich hospodárenia. $\mathrm{V}$ rámci globálneho civilizačného pokroku sa ich sociálne postavenie nezlepšuje a aj stagnácia znamená prehlbovanie priepasti $\mathrm{v}$ porovnaní so vzrastajúcou životnou úrovňou majority. ${ }^{20}$

\section{MEDZIGENERAČNÉ A INTERPERSONÁLNE VZŤAHY V RODINE, PRÍBUZENSTVE A SUSEDSTVE}

V zmysle moslimského náboženského učenia a beduínskej tradície je pre minoritnú beduínsku kultúru charakteristické dominantné postavenie starších nad mladšími a mužov nad ženami. Najstarší muž v rodine má právo vyžadovat poslušnost všetkých členov a teší sa prirodzenej úcte. Autoritatívne postavenie muža sa prejavuje vo vztahoch s manželkou aj det’mi - žena je reálne po celý život závislá od muža - dcéra od otca a manželka od manžela. Sami beduíni hovoria, že otec je minister zahraničných vecí - zastupuje rodinu navonok. Pred úradmi, v rámci lokálneho spoločenstva, susedstva aj príbuzenstva. Bez jeho súhlasu nikto z rodiny neodchádza zo stanu, nemá vlastné peniaze, nič nekúpi, nedojednáva a nevybavuje pre seba ani iných členov rodiny. Stratégiu medzigeneračných a interpersonálnych vztảahov určujú kmeňové tradície a korán. Návod na riešenie konkrétnych situácií podla ich závažnosti a významu dáva otec na základe vlastného uváženia, po porade s manželkou, prípadne po prediskutovaní a prehodnotení so staršími mužmi z príbuzenstva alebo so šejkom. Správnost predchádzajúcich alebo nasledujúcich postupov je diskutovaná a hodnotená pri stretnutiach mužov $\mathrm{v}$ madafe, čo možno považovat za priebežnú kontrolu aj oponentúru správnosti dodržiavania kultúrnych vzorov a zároveň aj zabezpečovanie socializácie.

Ak sú synovia v spoločnej domácnosti s rodičmi, sú zaviazaní poslušnostou otcovi až do jeho smrti. Podmienkou je, aby sa synovia navzájom znášali a s otcom sa rešpektovali. On roz-

20 Pri príležitosti svadby, narodenia syna, oslave ukončenia výučby koránu u náboženského šejka a najväčších sviatkov u moslimov otec kupuje každému členovi rodiny všetky odevné súčiastky a topánky nové. Dáva šit, alebo kupuje hotové. Tak to káže viera. Beduín je natolko veriaci a natolko hrdý, že to bezvýhradne dodržiava, ak aj iní celkom nie. On musí, lebo okrem iného tým dokazuje sebe aj iným, že nie je chudobný, že na to má. Zároveň to vyžaduje aj od iných- ak by neprišli k nemu pri narodení syna alebo na svadbu v novom, zneuctili by ho a jeho rodinu. Íst na svadbu nie je finančne jednoduché. Na nasledujúcu svadbu, aj keby bola o týždeň, musí byt všetko oblečenie nové. Beduínska svadba - priame nevyhnutné náklady: veno 110000 lír, 10 baranov 100000 lír, hudobná skupina 20000 lír, kameraman 5000 lír, mäsiar 4000 lír, 400 stoličiek 2500 lír, oblečenie pre 10 členov rodiny 50000 lír. 


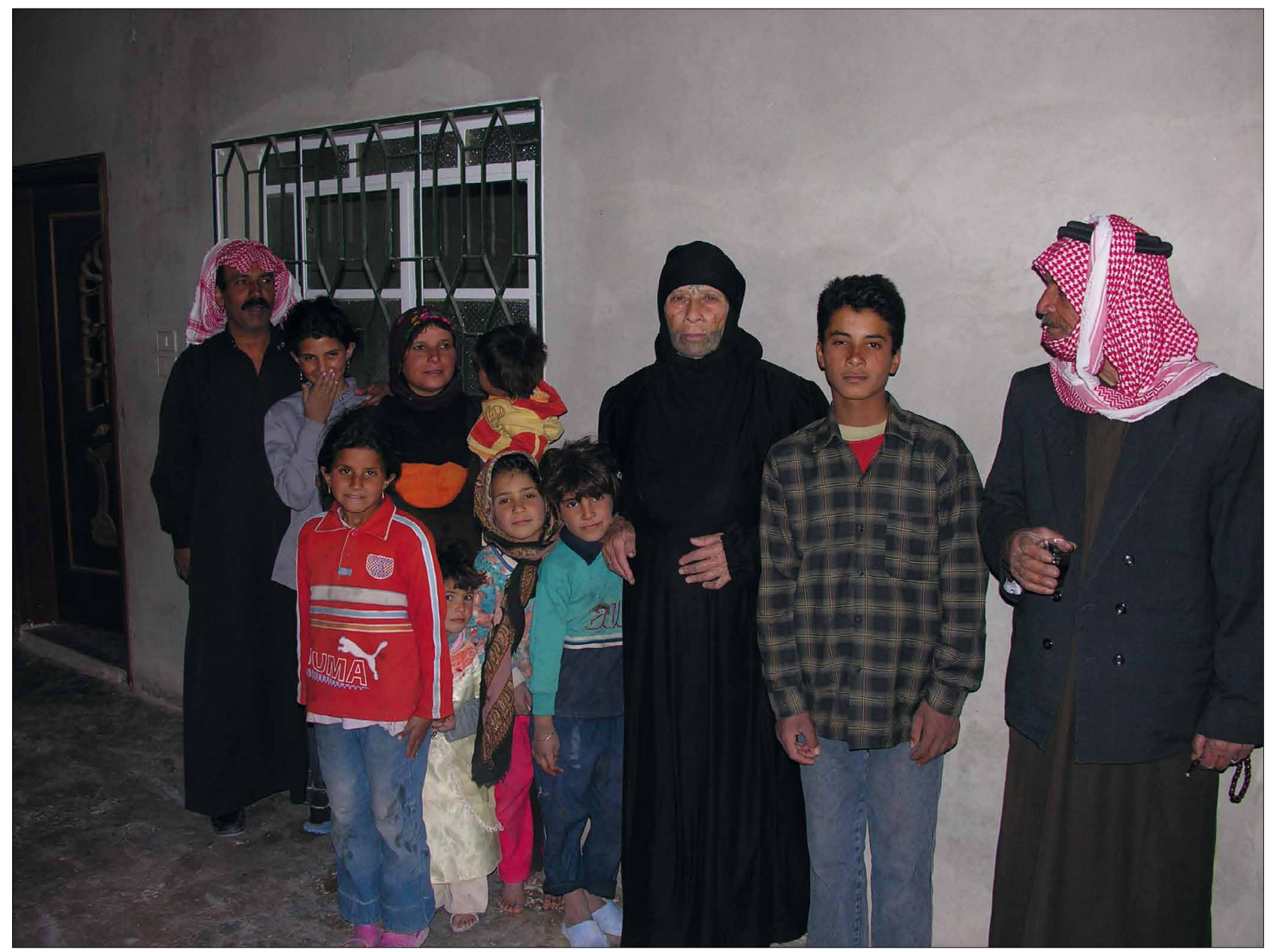

Obr. 9. Tri generácie v beduínskej dedine, 2008.

hoduje, či sa synovia, nevesty ${ }^{21}$ a slobodné dcéry zamestnajú a kde. Bez zarobených peňazí, len z úžitku z oviec, by rodiny neprežili. Je však prirodzené, že práca a zárobky mimo tradičnej sféry autoritu otca oslabujú, mladým rodinným príslušníkom sa otvára priestor na vlastné názory, polemiku a úvahy nad samostatnou existenciou. Tradičný kultúrny systém bol podmienený spolužitím rodičov so ženatými synmi, v opačnom prípade sa stáva nefunkčným. Otec si isto uvedomuje, že bez peňazí synov a práce neviest by nedokázal prenajímat pozemky, kupovat' krmivo a pohonné hmoty, sami dvaja s manželkou a slobodnými dcérami by už ovce nevládali pást', dojit', spracovávat mlieko. Hrá sa na pravého slobodného beduína, vyžaduje poslušnost', no opatrne, citlivo, lebo sa

21 Manželstvá sú patrilokálne alebo neolokálne, nikdy matrilokálne. Do manželstva môžu vstúpit len duševne zdraví, telesná chyba nie je podstatným problémom. Mladá žena vo veku 20 - 30 rokov $s$ malou telesnou alebo rečovou chybou sa vydá za vdovca staršieho o 50 rokov, aby sa ekonomicky zabezpečila. Nie sú známe prípady, aby sa mladý muž oženil so ženou staršou o viac ako 4-5 rokov, lebo žena rýchlejšie starne. obáva chvíle, kedy synovia oznámia, že už dalej nemôžu bývat’ v stane. V stane bývali preto, aby mohli chodit’ s ovcami po púšti a zastavit’ sa, kde je tráva. Ovce a stan boli základom ich existencie, od oviec a otca boli závislí. Teraz bývajú nedôstojne $\mathrm{v}$ stane na okraji dediny a nežijú $\mathrm{z}$ oviec, ale kvôli ovciam a preto, lebo sú bedu. Zarábajú v priemysle, aby ovce nepohynuli od hladu a nemôžu o sebe slobodne rozhodovat', lebo sú bedu. Keby púšt poskytovala to, čo pred niekolkými desatročiami, situácia by sa tak prudko neradikalizovala. Počasie mení medzigeneračné aj medziosobné vztahy a v konečnom dôsledku aj identitu beduínov. Všetko však záleží od momentálnej situácie - dostatku paše, miesta, kde sa práve rodina nachádza a aké je jej zloženie, či je obdobie dojenia a mlieko predávajú alebo ho spracovávajú doma a podobne. Ak sa práve dojí, stále sa pasie a robí sa s mliekom, priváža sa voda, krmivo, treba varit', prat', upratovat' v stane aj okolo neho. $\mathrm{V}$ púšti stačí na pasenie jeden, na prenajatých pozemkoch $\mathrm{v}$ blízkosti repy, kukurice, obilia alebo zeleniny najmenej traja, aby stádo neurobilo rolníkom škodu. Tu však netreba venovat' tol'ko času a prostriedkov na zabezpečovanie vody. 


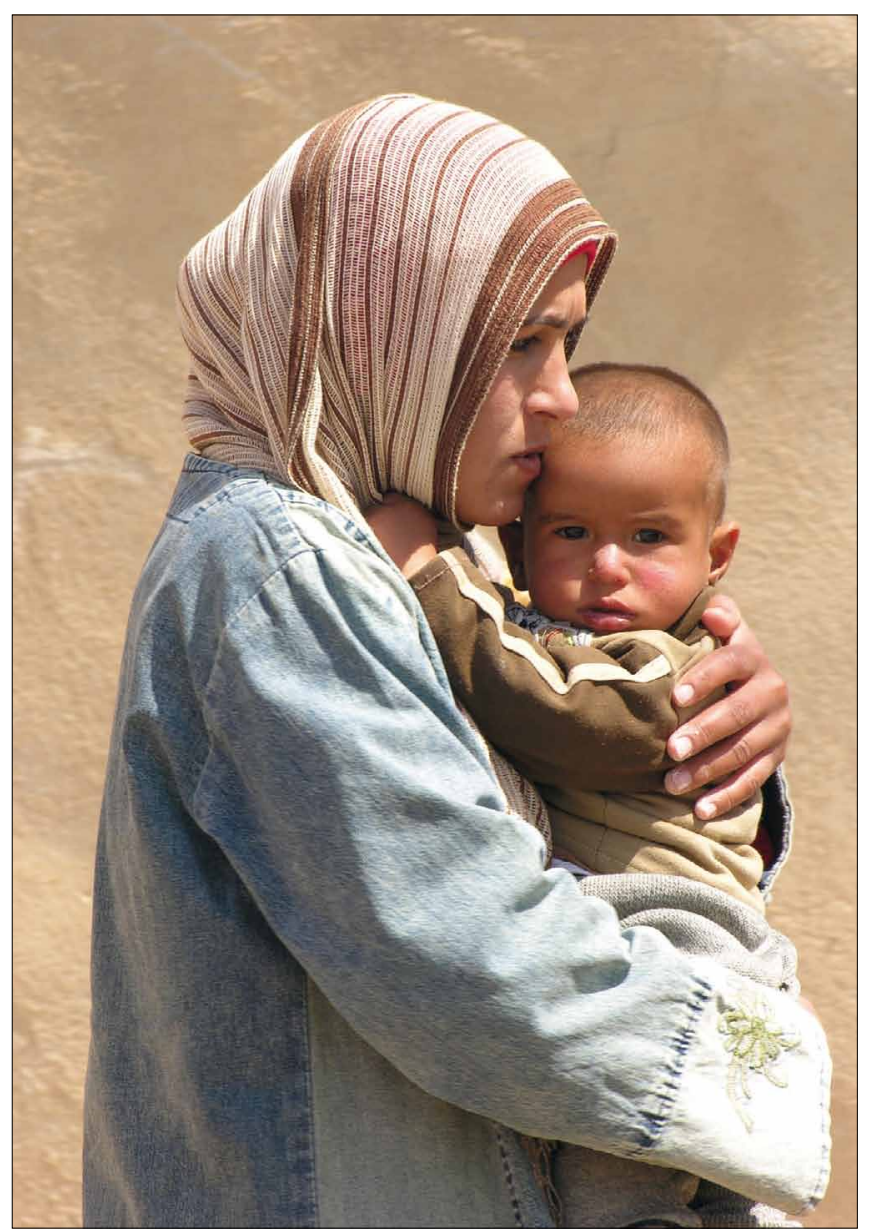

Obr. 10. Matka s dietatom, 2008.

Všetky zarobené a získané peniaze zhromažduje otec. On posudzuje, čo si potrebujú kúpit a čo dá jednotlivým členom rodiny. Ak synovia fajčia, nedovolia si pred rodičmi, len tajne. Otec má v rodine posledné slovo. Záleží od jeho a manželkiných osobnostných kvalít, do akej miery pri rozhodovaní kooperujú. Ak sa kupuje niečo pre dcéry a nevesty, ide do mesta s manželkou a ona vyberie. Alebo ide s nimi matka a otec tovar následne zaplatí. Vo všeobecnosti otec organizuje synov, svokor sa nemieša do neviest a dcér. Napomína ich a prácu im zadeluje svokra/matka. Každá žena má vlastnú predstavu o vedení domácnosti. Od nej záleží, čo vedia robit jej dcéry a na čo používat nevesty. Muž často ani netuší, čo nevesty nevedeli a čo ich naučila jeho manželka. V každom prípade musí byt nevesta krásna mat vysokú svetskú aj cirkevnú morálku, musí byt slušná a poslušná, rešpektovat’ rodičov aj susedov, byt’ pracovitá, dbat' o rodinu. Musí vediet' varit'. Ak niečo nevie, napríklad šit, svokra ju naučí. Ani dieta nevie a $v$ škole sa naučí. Dcéram venuje matka menšiu pozornost̉ a príliš nemieni investovat do ich schopností a zručností. Pasú, doja, zarábajú peniaze u rolníkov. Skôr či neskôr odídu do nového rodinného a rezidenčného prostredia - nech ich svokra naučí, čo bude od nich v danej situácii potrebovat. Nové nevesty a dcéry pri

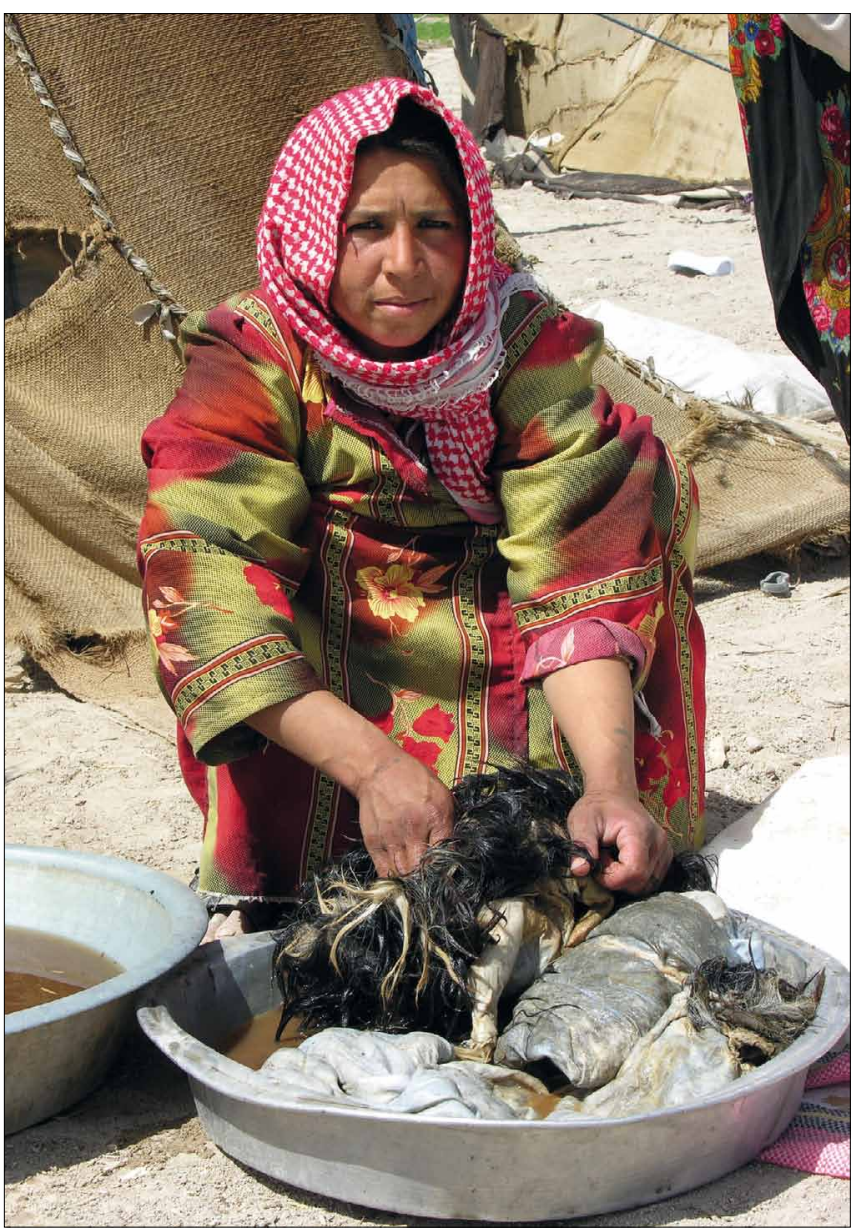

Obr. 11. Pranie kože, 2008.

varení, pečení, praní, spracovávaní mlieka ... matka spočiatku strieda, aby videla, ktorá má v čom lepšie schopnosti. Ak je to potrebné, kúpi aj šijací stroj a naučí niektorú nevestu šit', lebo to nie je len na pár rokov ako v prípade vlastnej dcéry. Na špeciálne príležitosti - napríklad varenie a pečenie pri významných rodinných udalostiach pre množstvo hostí - pozve staršia gazdiná spravidla svoju najdlhšie vydatú dcéru, lebo je predpoklad, že ako nevesta sa už všetko potrebné naučila. Okamžite príde pomôct’ rodičom. Gazdiná sedí a sleduje ako práce organizuje a riadi jej dcéra a všetky mladšie sestry a švagriné ju rešpektujú. Pošle ich napríklad po sol' a sama solí aj ochutnáva. Ak sa raz vydatá dcéra sama ocitne v núdzi, napríklad jej ochorie manžel, otec jej vždy pomôže. Žiadne také, že vydala si sa, máš svoju rodinu, starajte sa. Si otec a o deti sa musíš starat do smrti. A deti musia pomôct' tebe ${ }^{22}$ (muž, 62 rokov).

22 Pred odchodom na príležitostnú návštevu rodiny svojej dcéry niekolko desiatok kilometrov do púšte povedal: ideme môjmu zato$v i$. Nabral do vreca od rolníkov paradajky, papriku, karfiol, nakúpil chlieb a sladkosti. Zvítal sa so zatom, vybozkával si vnúčatá a vlastnú dcéru si akoby nevšimol, hoci medzi nimi existuje hlboký citový vztah a spolupatričnost'. 


\section{BEDUÍNI A ŠTÁT}

Štát neuprednostňuje beduínov ani inú subkultúru, nikoho pozitívne nediskriminuje. Cielavedome sa snaží odpútat beduínov od výhradnej závislosti od prírodného prostredia. Finančne ich nepodporuje priamo, ale stimuluje k ekonomickým aktivitám v rámci usadlého spôsobu života. Poskytuje výhodné úvery na stavbu domov, nákup mechanizmov na zúrodňovanie púšte a zavlažovanie polnohospodárskej pôdy, zakladanie stád hovädzieho dobytka. Ak úvery nevládzu splácat', štát ich niekedy odpúšta. V̌setko smeruje $\mathrm{k}$ zlepšovaniu životnej úrovne na vidieku, aby sa dedinské obyvatelstvo a beduíni nestahovali do miest. Beduíni nemajú žiadne sociálne podpory ak nepracujú a nijaké limity ani úlavy pri prijímaní na univerzity. Študujú chlapci aj dievčatá, mnohí vzdelaní beduíni sú lekári, zamestnanci na vysokých postoch $\mathrm{v}$ štátnych službách, majú zastúpenie v parlamente. Osudy jednotlivcov napriek tomu často závisia od sily tradície kmeňového systému a vôle šejkov rodín a ašír. Šejkovia sú lojálni voči štátnej moci, no vo vztahoch je primárna kmeňová hierarchia. Tá je nadradená nad všetky zákony. Nekonformnost' v rámci kmeňa sa netoleruje na žiadnej úrovni.

\section{TRADIČNÁ KULTÚRA A GLOBALIZÁCIA - PROCES KULTÚRNYCH ZMIEN}

Od poslednej tretiny 20. storočia - v súvislosti s aktivitami štátu a klimatickými zmenami - beduíni postupne nadobúdajú presvedčenie, že je potrebné mat sa kde vrátit. Mnohí muži z najstaršej generácie, žijúci pod stanom, sa však do vlastných zariadených domov obávajú vstúpit čo len na chvílu, a nechcú tam pustit ani svojich synov. Pôdu pri dome neobrábajú pod rôznymi zámienkami. Nechcú riskovat', že sa im tam zapáči, že by náhodou na vlastnej koži zistili, že je tam lepšie, pohodlnejšie, čistejšie a istejšie. Narušila by sa tým ich autorita aj beduínsky mýtus slobody. Dobrodružstvo a neistota sú neodmyslitelnou súčastou ich života a nemienia sa ich vzdat. Tvrdohlavo odolávajú na pomedzí púšte a dediny a v posledných rokoch života sa len hrajú hru na beduínov. $V$ púšti nebýva tráva a z pasenia oviec sa na horúcom piesku a v skalách vyžit nedá. Musia byt v blízkosti sídel a zárobkových príležitostí pre svojich synov a nevesty. Vyhovárajú sa, že do púšte nemôžu odíst kvôli školopovinným detom, no v skutočnosti by už bez príjmov starších synov neprežili a elektrina, dostatok vody a iné lákadlá majú čoraz silnejšiu moc. Beduíni preto postupne modifikujú kočovný spôsob života, rýchlym tempom zahrievajú, intenzifikujú svoju kultúru. Ešte pred piatimi - šiestimi rokmi sa obklopovali len predmetmi, ktoré nevyhnutne pravidelne potrebovali a nebolo problémom rýchlo sa zbalit a presunút na iné miesto. Každá kultúra disponuje aj takými hodnotami, ktoré sú potrebné len sporadicky. Mobilné sklady nedovolovali vytvárat nevyužívané zásoby, najmä tie materiálne by boli stálou prítažou. Nesmierne duchovné bohatstvo kočovnému spôsobu života neprekážalo, bolo jeho nevyhnut- nou súčastou, ozdobou a kompenzáciou absentujúcich hodnôt z kategórie materiálno - technologickej kultúry. Dnes dochádza $\mathrm{k}$ situácii, kedy začína kultúra pod beduínskym stanom vzdychat pod váhou elektrických generátorov a akumulátorov, varičov, televízorov, chladničiek, automatických pračiek, elektrických mlynčekov na kávu, videoprehrávačov, šijacích strojov, plynových a mazutových pecí, svietidiel a mobilných telefónov. Všetky lákajú do pohodlnejších sfér, vytláčajú tradičné hodnoty a kultúrne vzory, menia normy, zneistujú všetkých, ktorí si vážia predkov, ctia tradície. Rušia vychodené chodníky, ponúkajú zdanlivo výhodné, nové, no neoverené cesty, nútia experimentovat'. Nové tovary a služby sú bez návodu na použitie. Pribíjajú stany nomádov $\mathrm{k}$ jednému miestu, ich váha znemožňuje pohyb, ktorý je synonymom života. Najmä mladí si uvedomujú, že majú príležitost presadit' sa, prezentovat' svoje osobné schopnosti a dokázat', že nie sú len do počtu. Individualizmus, hlad po západnej slobode a demokracii narúšajú štruktúry sociálnej kontroly a váhu konformity, spochybňujú význam princípu autoritatívnosti, slobodný život v púšti ako základ beduínskej kolektívnej identity. Beduíni sa nenápadne resocializujú na rolníkov a popri tom aj na šoférov, obchodníkov, murárov, zámočníkov, mäsiarov, kvetinárov, učitelov a úradníkov. Dochádzanie zo stanu do práce v meste je posledným výkrikom, zúfalstvom. Je to na hranici bedu a civilizácie. Bedu sa snaží byt nezávislý, ale pri dedine už reálne nezávislost stratil, alebo ju rýchlo stráca. Rolník sa stáva jeho pánom rozhoduje či mu prenajme pozemok na pasenie a za kolko. Príroda (sucho) vzala beduínovi volnost' a slobodu, zárobky rúcajú jeho autoritu, rolník mu berie hrdost', chudoba znemožňuje pohostinnost' a nezištnoste. Problémy s prežitím a najrôznejšie spôsoby ich riešenia spôsobujú, že pomaly ani nebude koho hostit. Ak by platilo, že bedu je skromný, málo podnikavý, neprispôsobivý a zaostalý lebo je tvrdohlavý, ani jedna z týchto vlastností sama o sebe neznamená prežitie. Napriek tomu, alebo práve preto je obdivuhodný. Beduín je zviazaný tradíciou. Nerozmýšla príliš ako veci zmenit, ale pokúša sa uspokojivo vysvetlit a ospravedlnit', ak sa niečo presne neriadilo tradíciou.

Napriek tomu, že islam ponúka návod na konformný a bezproblémový život všetkých moslimov, beduíni majú svoje špecifické cesty života, hodnoty, ciele a túžby, ktoré ich odlišujú od obyvatelov dedín a miest. Nie je dôležité, čo má oblečené, či je ostrihaný, potetovaný, má jednu alebo dve manželky - kým má bedu ovce a býva $\mathrm{v}$ stane, stále prosí Boha, aby bola v púšti tráva - aj ked’ sám tuší, že sa tam už vrátit nemôže.

Od posledného terénneho výskumu beduínov v Sýrskej púšti v roku 2010 ovplyvňujú ich spôsob života vojnové konflikty. Nedokážeme odhadnút,', či príslušníci kmeňov v oblasti Al-Lažat na juhozápade, v okolí Palmíry alebo Rakky, ktoré sme opakovane navštevovali, ešte vôbec žijú. Ich kultúru už zdaleka neformuje len prírodné prostredie, ale ocitla sa v strede zložitého vztahového kruhu mnohých vonkajších faktorov, ktoré postupne menia podstatu jej systému. 


\section{LITERATÚRA}

Dicson, H. R. B. (1998): Arab al Sahra. Z angl. orig. do arab. prel. Dar al Fikr, Damascus.

Frantzman, S. - Kark, R. (2011): Bedouin Settlement in Late Ottoman and British Mandatory Palestine: Influence on the Cultural and Enviromental Landscape. In: New Middle Eastern Studies 1, 1-24. Online at: http:// www.brismes.ac.uk/nmes/?s=kark

Hasan, N. M. (2005): Mantiqat al Lazat al Waira. Damascus: Al Chansa.

Havrlant, M. - Buzek, L. (1985): Nauka o krajině a péče o životní prostředí. Praha: SPN.

Heřmanová, E. - Chromý, P. a kol. (2009): Kulturní regiony a geografie kultury. Praha: ASPI

Hughes, H. (1981): Middle East Railways - The Continental Railway Circle. Harrow: Middx.

Hourani, A. (2010): Dějiny arabského světa od 7. století po současnost. Z angl. orig. A History of the Arab Peoples preložil Šimon Pellar. Praha: Nakladatelství Lidové noviny.

Louhaichi, M. (2012): Effect of sheep grazing on rangeland plant communities: Case study of landscape depressions within Syrian arid steppes. Journal of Arid Environments, 24(79), 101-106.

Philip, G. et al. (2007): Natural and cultural aspects of the development of the Marl landscape east of Lake Qatina durign the Bronze and Iron Ages. In: Urban and natural landscapes of an ancient Syrian capital: settlement and enviroment at Tell Mishrifeh and in central-western Syria. Udine: Forum Editrices, 233-242.

Philip, G. et al. (2008): Settlement and landscpae development in the Homs region. In: Syria: report on work undertaken during 2001-2003. Levant, $21-42$.
Shmueli, A. (1980): The Bedouin of the land of Israel - Settlement and changes. Urban Ecology, 4(4), 253-286.

Tesař, F. (2007): Etnické konflikty. Praha: Portál.

Zakarija, A. W. (2005): Asaer al Saam. Z angl. orig. do arab. prel. Dar al Fikr. Damascus.

\section{AUTORI}

Čukan, Jaroslav prof., PhDr., CSc. (1954) slovenský etnológ a kulturológ. Venuje sa prevažne výskumu kultúry slovenských minoritných spoločenstiev v zahraničí. Skúmal aj Beduínov v Sýrii, kde realizoval niekolko opakovaných dlhodobých terénnych výskumov.

Michalík, Boris doc., PhDr., Ph.D. (1981) kulturológ a odborník na minoritný manažment. Venuje sa identite a kultúre menšinových spoločenstiev.

Čukanová, Linda, Mgr. (1991) je dennou doktorandkou v odbore kulturológia na KMKT FF UKF v Nitre. Ako absolventka kulturológie v špecializácii blízkovýchodné štúdia sa venuje výskumu tradičnej kultúry blízkovýchodných krajín aj spôsobu života arabsko-moslimských pristahovalcov na Slovensku.

Žabenský, Marián, PhDr., PhD. (1984) je kulturológ a kultúrny geograf. Venuje sa skúmaniu vzájomného vztahu človeka, prírody a kultúry. 